\title{
Development of a plume-in-grid model for industrial point and volume sources: application to power plant and refinery sources in the Paris region
}

\author{
Y. Kim ${ }^{1}$, C. Seigneur ${ }^{1}$, and O. Duclaux ${ }^{2}$ \\ ${ }^{1}$ CEREA, Joint Laboratory École des Ponts ParisTech/EDF R\&D, Université Paris-Est, 77455 Champs-sur-Marne, France \\ ${ }^{2}$ CRES, Centre de Recherche TOTAL, 69360 Solaize, France \\ Correspondence to: Y. Kim (kimy@ cerea.enpc.fr)
}

Received: 30 September 2013 - Published in Geosci. Model Dev. Discuss.: 27 November 2013

Revised: 19 February 2014 - Accepted: 20 February 2014 - Published: 4 April 2014

\begin{abstract}
Plume-in-grid (PinG) models incorporating a host Eulerian model and a subgrid-scale model (usually a Gaussian plume or puff model) have been used for the simulations of stack emissions (e.g., fossil fuel-fired power plants and cement plants) for gaseous and particulate species such as nitrogen oxides $\left(\mathrm{NO}_{\mathrm{x}}\right)$, sulfur dioxide $\left(\mathrm{SO}_{2}\right)$, particulate matter $(\mathrm{PM})$ and mercury $(\mathrm{Hg})$. Here, we describe the extension of a PinG model to study the impact of an oil refinery where volatile organic compound (VOC) emissions can be important. The model is based on a reactive PinG model for ozone $\left(\mathrm{O}_{3}\right)$, which incorporates a three-dimensional (3-D) Eulerian model and a Gaussian puff model. The model is extended to treat PM, with treatments of aerosol chemistry, particle size distribution, and the formation of secondary aerosols, which are consistent in both the 3-D Eulerian host model and the Gaussian puff model. Furthermore, the PinG model is extended to include the treatment of volume sources to simulate fugitive VOC emissions. The new PinG model is evaluated over Greater Paris during July 2009. Model performance is satisfactory for $\mathrm{O}_{3}, \mathrm{PM}_{2.5}$ and most $\mathrm{PM}_{2.5}$ components. Two industrial sources, a coal-fired power plant and an oil refinery, are simulated with the PinG model. The characteristics of the sources (stack height and diameter, exhaust temperature and velocity) govern the surface concentrations of primary pollutants $\left(\mathrm{NO}_{\mathrm{x}}, \mathrm{SO}_{2}\right.$ and $\left.\mathrm{VOC}\right) . \mathrm{O}_{3}$ concentrations are impacted differently near the power plant than near the refinery, because of the presence of VOC emissions at the latter. The formation of sulfate is influenced by both the dispersion of $\mathrm{SO}_{2}$ and the oxidant concentration; however, the former tends to dominate in the simulations presented here. The
\end{abstract}

impact of PinG modeling on the formation of secondary organic aerosol (SOA) is small and results mostly from the effect of different oxidant concentrations on biogenic SOA formation. The investigation of the criteria for injecting plumes into the host model (fixed travel time and/or puff size) shows that a size-based criterion is recommended to treat the formation of secondary aerosols (sulfate, nitrate, and ammonium), in particular, farther downwind of the sources (beyond about $15 \mathrm{~km})$. The impacts of PinG modeling are less significant in a simulation with a coarse grid size $(10 \mathrm{~km})$ than with a fine grid size $(2 \mathrm{~km})$, because the concentrations of the species emitted from the PinG sources are relatively less important compared to background concentrations when injected into the host model with a coarser grid size.

\section{Introduction}

An Eulerian air quality model calculates concentrations of pollutants in a three-dimensional (3-D) grid and the modeled concentrations are spatially uniform within each grid cell. Therefore, emissions are necessarily diluted immediately in the volume of the grid cell(s) where they are injected. This modeling approach can lead to significant errors for emission sources that have much smaller dimensions than those of the grid cells. These errors include underestimation of emitted species concentrations downwind of the source due to the instantaneous emission dilution, overestimation of emitted species concentrations upwind of the source and in other model layers (e.g., in the surface layer) 
due to the instantaneous emission dilution in the source grid cell and subsequent transport and diffusion processes, and incorrect concentrations of secondary pollutants due to chemical transformations involving under- or overestimated concentrations of emitted species (e.g., Seigneur et al., 2006; Karamchandani et al., 2011). The errors can be reduced by coupling a plume or puff model with the Eulerian model to create a multi-scale model, typically referred to as a plumein-grid (PinG) model.

PinG modeling has been used for ozone $\left(\mathrm{O}_{3}\right)$ since the 1980s (Karamchandani et al., 2011). It was later extended to particles (Karamchandani et al., 2006). These models were evaluated for $\mathrm{O}_{3}$ and $\mathrm{PM}_{2.5}$ (fine particles with an aerodynamic diameter less than 2.5 micrometers). PinG modeling, compared to a standard grid-based Eulerian model simulation, typically leads to a spatial redistribution of $\mathrm{O}_{3}$ concentrations due to its interaction with nitrogen oxides $\left(\mathrm{NO}_{\mathrm{x}}\right)$, but a negligible effect on the domain-wide $\mathrm{O}_{3}$ budget (e.g., Seigneur et al., 1981; Kumar and Russell, 1996; Karamchandani et al., 2002). On the other hand, PinG modeling for fossil fuel-fired power plants led to lower concentrations of secondary sulfate and nitrate particles in a simulation over the eastern United States, because of lower oxidant concentrations in the plumes (Karamchandani et al., 2006).

The performance of a PinG model (or its subgrid-scale model) has been evaluated with measured in-plume concentrations. Vijayaraghavan et al. (2006) compared concentrations simulated with a subgrid-scale puff model (SCICHEM) used in a PinG model (CMAQ-APT) with aircraft measurements of power plant plumes. Modeled plume excess concentrations (i.e., the differences between the plume and background concentrations) of $\mathrm{NO}_{\mathrm{x}}$ and $\mathrm{O}_{3}$ showed good agreement with measured concentrations about $4 \mathrm{~km}$ downwind of the sources. Karamchandani et al. (2006) introduced an approach to calculate subgrid-scale concentrations using a similar PinG model (CMAQ-MADRID-APT) that accounts for uncertainty in the wind direction by calculating the concentration at a receptor site along an arc centered at the source and extending $30^{\circ}$ on each side of the receptor site. The source impacting the site was identified based on the sulfur dioxide $\left(\mathrm{SO}_{2}\right) / \mathrm{NO}_{\mathrm{x}}$ plume excess ratio and the backtrajectory. The subgrid-scale concentrations showed variability in $\mathrm{SO}_{2}$ concentrations within the grid cell of a factor of three and reproduced the plume concentration observed at the receptor site. The Eulerian model (i.e., without PinG treatment) underestimated this observed concentration by a factor of two.

Previous studies using PinG models have focused mostly on the simulation of elevated point source emissions such as fossil fuel-fired power plant and cement plant stacks. Power plants burning coal and fuel oil emit $\mathrm{NO}_{\mathrm{x}}$ and $\mathrm{SO}_{2}$, but emit negligible amounts of volatile organic compounds (VOC). $\mathrm{NO}_{\mathrm{x}}$ emissions, which principally consist of nitric oxide (NO) $(>90 \%)$ consume oxidants such as $\mathrm{O}_{3}$ and hydroxyl radical $(\mathrm{OH})$ near the source. Since the combination of $\mathrm{NO}_{\mathrm{x}}$ and VOC emissions can lead to the formation of oxidants, it is of interest to apply a PinG model to study the impact of refineries where both $\mathrm{NO}_{\mathrm{x}}$ and $\mathrm{VOC}$ emissions can be important. However, VOC emissions result mostly from leaks and should be treated as fugitive emissions distributed spatially over a finite volume of the industrial site. Thus, the PinG model needs to be modified to account for volume sources in addition to point sources.

First, the development of the PinG model for gaseous and aerosol species due to emissions from point and volume sources is presented. Then, simulations are conducted to evaluate the effect of PinG modeling on two major types of industrial sources: a fossil fuel-fired power plant and a refinery. The simulation domain, the episode, the model configuration, and the treatment of sources are described. Model performance is evaluated by comparison to measurements and the impact of the PinG model on air pollutant concentrations due to emissions from the industrial sources is presented.

\section{Model development}

The Polyphemus version 1.8 (http://cerea.enpc.fr/ polyphemus/index.html) air quality platform and its PinG model (Korsakissok and Mallet, 2010a; Korsakissok and Mallet, 2010b) are used as a starting point for this work. The Polyphemus PinG model links a Gaussian puff model (Korsakissok and Mallet, 2009) and the Polair3D Eulerian model (Boutahar et al., 2004; Sartelet et al., 2007).

The Polyphemus Gaussian puff model treats the transport and the dispersion of puffs as well as the gas-phase chemical reactions occurring in the puffs in interaction with the ambient background. This model has been described by Korsakissok and Mallet (2010a). A brief description of the model is presented here to present the context for the addition of aerosols in the Gaussian puff model and the new treatment of volume sources.

Each puff transports all gaseous and particulate chemical species. The concentration distribution of a chemical species in the puff is assumed to be Gaussian and can be written as follows:

$C(x, y, z)=F\left(Q, \sigma_{x}, \sigma_{y}, \sigma_{z}\right)$,

where $\sigma_{x}$ and $\sigma_{y}$ are the Gaussian standard deviations on a horizontal plane, respectively in the wind direction and perpendicular to the wind direction, $\sigma_{z}$ is the Gaussian standard deviation in the vertical direction, and $Q$ is the mass of a species in the puff. That mass is defined as the species emission rate from the source multiplied by the time interval between two puffs released from that source.

In general, the Gaussian standard deviations for a point source, which is a single, identifiable source of air pollutant emissions, are given by empirical formulae: 


$$
\begin{gathered}
\sigma_{x}=\sigma_{x_{\text {turb }}}, \quad \sigma_{y}^{2}=\sigma_{y_{\text {turb }}}^{2}+\sigma_{y_{\mathrm{pr}}}^{2}+\frac{d_{\mathrm{s}}^{2}}{4}, \\
\sigma_{z}^{2}=\sigma_{z_{\text {turb }}}^{2}+\sigma_{z \mathrm{pr}}^{2},
\end{gathered}
$$

where $\sigma_{x_{\text {turb }}}, \sigma_{y_{\text {turb }}}$ and $\sigma_{z_{\text {turb }}}$ are the plume dispersion coefficients due to atmospheric turbulence, and $\sigma_{y_{\mathrm{pr}}}$ and $\sigma_{z_{\mathrm{pr}}}$ represent the added dispersion due to the plume rise. The term $\frac{d_{s}^{2}}{4}$ represents the initial standard deviation characterized by the diameter of the source $d_{\mathrm{s}}$ (Korsakissok and Mallet, 2009).

An algorithm was added to model the emissions of a volume source, which is a 3-D source of air pollutant emissions. Two algorithms have been used typically to treat volume sources in air pollutant dispersion models: one using a virtual source (US EPA, 1995) and one using initial plume dimensions (US EPA, 1995; Cimorelli et al., 2004). The former algorithm uses a virtual source located upwind of the actual volume source such that the plume dimensions at the location of the actual source correspond to the dimensions of that source. The location of the virtual source varies as a function of wind direction, wind speed, and atmospheric stability. The latter algorithm simply uses initial values of the standard deviations that are consistent with the dimensions of the source. The two approaches are mathematically identical and only differ in their numerical implementation. Here, the algorithm using the initial dimensions of the plume (or puff) is used. Following US EPA (1995), the initial dimensions of the puff for a volume source are given by

$\sigma_{x i}=\sigma_{y i}=\frac{1}{4.3} \sqrt{x^{2}+y^{2}}, \quad \sigma_{z i}=\frac{z}{4.3}$,

where $x, y$ and $z$ are, respectively, the length, the width, and the height of the volume source.

The term $\frac{d_{\mathrm{s}}^{2}}{4}$ of Eq. (2) is therefore replaced by $\sigma_{y i}$. Additional terms $\sigma_{x i}$ and $\sigma_{z i}$ are added to $\sigma_{x}$ and $\sigma_{z}$, respectively. The plume rise is negligible for a volume source because fugitive emissions have little impact on the ambient temperature of the volume source domain. Therefore, we obtain the following formulations for the puff standard deviations of a volume source:

$$
\begin{gathered}
\sigma_{x}^{2}=\sigma_{x_{\text {turb }}}^{2}+\sigma_{x i}^{2}, \quad \sigma_{y}^{2}=\sigma_{y_{\text {turb }}^{2}}^{2}+\sigma_{y i}^{2}, \\
\sigma_{z}^{2}=\sigma_{z_{\text {turb }}}^{2}+\sigma_{z i}^{2} .
\end{gathered}
$$

Following the modeling approach used in the SCICHEM reactive puff model (Karamchandani et al., 2000), the concentrations of the chemical species in each puff are treated as perturbations $(\Delta c)$ of the background concentrations,

$\Delta c=c^{\mathrm{p}}-c^{\mathrm{b}}$,

where $c^{\mathrm{p}}$ is the concentration in the puff and $c^{\mathrm{b}}$ is the concentrations modeled by the Eulerian host model, i.e., the background concentration. To calculate the concentrations of the species in the puff, we use the procedure described by Korsakissok and Mallet (2010a):
1. Let a chemical reaction in a puff be $\mathrm{A}+\mathrm{B} \rightarrow \mathrm{P}$, where $\mathrm{A}$ and $\mathrm{B}$ are gas-phase or particulate species. The concentrations of the species $\mathrm{A}$ and $\mathrm{B}$ in the puff at time $t$ are $c_{\mathrm{A}}^{\mathrm{p}}(t)$ and $c_{\mathrm{B}}^{\mathrm{p}}(t)$. These puff concentrations correspond to the background concentration $c^{\mathrm{b}}$ added to the perturbation of the puff $\Delta c$.

2. The new concentrations of the species $A$ in the puff due to the chemical reaction is computed for the time step $\Delta t$. The reaction rate of the species $\mathrm{A}$ in the puff is

$$
\begin{aligned}
& \frac{\mathrm{d} c_{\mathrm{A}}^{\mathrm{p}}}{\mathrm{d} t}=\frac{\mathrm{d}\left(c_{\mathrm{A}}^{\mathrm{b}}+\Delta c_{\mathrm{A}}\right)}{\mathrm{d} t} \\
& =-k(\underbrace{c_{\mathrm{A}}^{\mathrm{b}} c_{\mathrm{B}}^{\mathrm{b}}}_{(1)}+\underbrace{c_{\mathrm{A}}^{\mathrm{b}} \Delta c_{\mathrm{B}}+c_{\mathrm{B}}^{\mathrm{b}} \Delta c_{\mathrm{A}}}_{(2)}+\underbrace{\Delta c_{\mathrm{A}} \Delta c_{\mathrm{B}}}_{(3)}),
\end{aligned}
$$

where $k$ is the rate constant, (1) represents the background chemistry, (2) is the interaction between the puff and the background species, and (3) is the chemistry specific to the puff.

3. The new background concentration due to the chemical reaction is computed separately from the previous equation for the time step $\Delta t$. The reaction rate for species $\mathrm{A}$ in the background is

$\frac{\mathrm{d} c_{\mathrm{A}}^{\mathrm{b}}}{\mathrm{d} t}=-k\left(c_{\mathrm{A}}^{\mathrm{b}} c_{\mathrm{B}}^{\mathrm{b}}\right)$.

4. The new background concentration is subtracted from the new puff concentration to obtain the new perturbation of the puff. The reaction rate representing the perturbation is then

$$
\frac{d \Delta c_{\mathrm{A}}}{\mathrm{d} t}=-k(\underbrace{c_{\mathrm{A}}^{\mathrm{b}} \Delta c_{\mathrm{B}}+c_{\mathrm{B}}^{\mathrm{b}} \Delta c_{\mathrm{A}}}_{(2)}+\underbrace{\Delta c_{\mathrm{A}} \Delta c_{\mathrm{B}}}_{(3)}) .
$$

The new perturbation of the puff corresponds to the terms (2) and (3) in Eq. (6).

The original formulation of the Polyphemus PinG model pertained only to gaseous species. Therefore, the model was also modified to treat particulate species. To that end, the following modules were included in the Gaussian puff model to simulate the concentrations of particles in the puff: the CB05 mechanism (Yarwood et al., 2005) for the gas-phase chemistry, the SIREAM model (Debry et al., 2007) for the particle size distribution, the ISORROPIA model (Nenes et al., 1998) for inorganic aerosol species, and the $\mathrm{H}^{2} \mathrm{O}$ model (Couvidat et al., 2012) for organic aerosol species. Aqueous-phase chemistry is simulated using a model, which treats $\mathrm{SO}_{2}$ oxidation and the gas/liquid and ionic equilibria of major watersoluble species (Tombette, 2007). 
The aerosol- and aqueous-phase models were implemented in the Gaussian puff model in the same way as they were implemented in the Eulerian host model for the sake of consistency. In the PinG model, the perturbations of the puff concentrations were calculated at each time step first for the gas-phase species and next for the particulate species.

\section{Description of the simulations}

The model presented in the previous section was applied to the Paris region (Greater Paris) for a three-week simulation. Two industrial sources are treated explicitly with the PinG representation: a coal-fired power plant and a refinery. The simulation configurations are described below.

\subsection{Simulation setup}

The air quality simulations were carried out to evaluate the impact of the PinG model on the concentrations of $\mathrm{O}_{3}$ and $\mathrm{PM}_{2.5}$. Three modeling domains are used with one-way nesting. The largest domain covers western Europe and part of eastern Europe with a horizontal resolution of $0.5^{\circ} \times 0.5^{\circ}$. The first nested domain covers France with a resolution of $0.1^{\circ} \times 0.1^{\circ}$ and the smallest domain covers Greater Paris with a resolution of $0.02^{\circ} \times 0.02^{\circ}$. The vertical resolution consists of 9 levels up to $12 \mathrm{~km}$ with a finer resolution near the surface. The altitudes of the vertical upper boundary of the grid cells are $40 \mathrm{~m}, 120 \mathrm{~m}, 300 \mathrm{~m}, 800 \mathrm{~m}, 1500 \mathrm{~m}, 2400 \mathrm{~m}$, $3500 \mathrm{~m}, 6000 \mathrm{~m}$, and $12000 \mathrm{~m}$. The smallest domain is presented in Fig. 1. The Weather Research and Forecast (WRF) model version 3.3 with the Advanced Research WRF (ARW) dynamics solver was used to simulate the meteorological fields over Greater Paris (Skamarock et al., 2008). The regular latitude-longitude map projection is used for the three simulation domains with one-way nesting. Horizontal grid spacing of the coarse domain is $0.5^{\circ}$ and those of the two nested domains are $0.1666^{\circ}$ and $0.0555^{\circ}$, respectively. The largest $0.5^{\circ}$ domain covers Europe and the smallest domain covers Greater Paris. The vertical resolution consists of 28 levels up to $100 \mathrm{hPa}$ (about $16 \mathrm{~km}$ ). The descriptions of the two coarser domains are given by Royer et al. (2011).

Two simulations over Greater Paris were carried out from 4 July to 29 July 2009 with six days of spin-up to initialize the simulation.

1. "Reference" simulation: the two industrial sources are treated in a standard way by the Eulerian model, i.e., their emissions are released into the appropriate grid cells.

2. "Plume-in-Grid (PinG)" simulation: the two industrial sources are treated with the subgrid-scale puff model.

For the PinG simulation, the time interval between puffs must be selected to reproduce the continuous plumes with sufficient accuracy as well as to restrict the computation time.

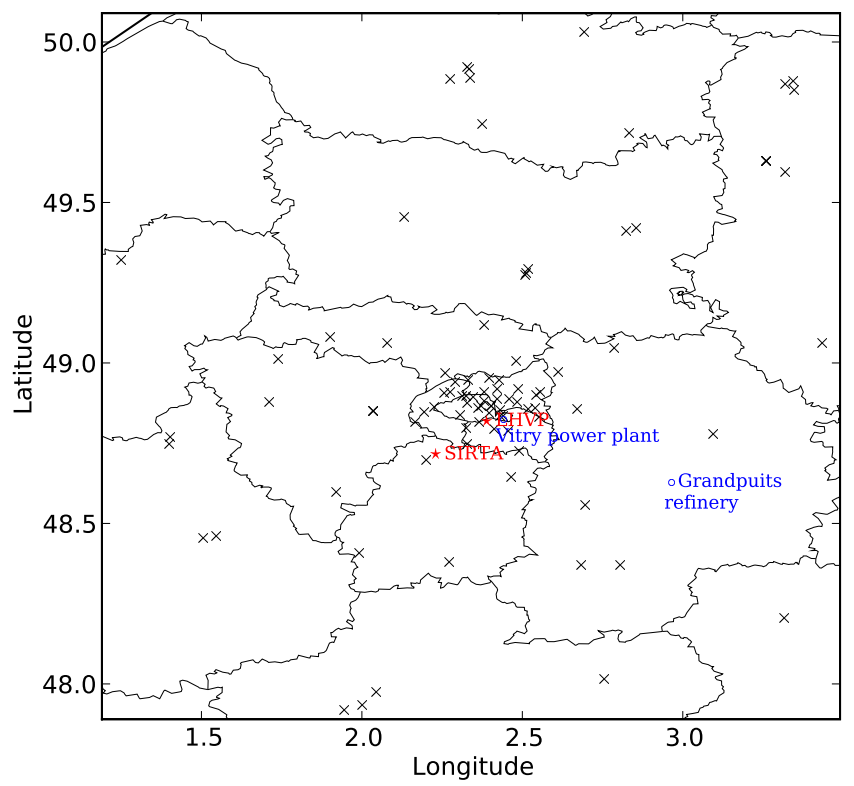

Fig. 1. Domain for the Greater Paris simulation with the locations of the two industrial sources selected for the PinG treatment (blue circles), the stations of the BDQA monitoring network (black crosses), and the stations operated during the Megapoli campaign (red stars).

Korsakissok and Mallet (2010b) investigated the sensitivity of PinG modeling to time intervals between puffs. They compared a simulation conducted using a time interval of $1 \mathrm{~s}$ to simulations using greater time intervals. The impact of using different time intervals was negligible for time intervals below $50 \mathrm{~s}$; the error was about $10 \%$, with a time interval of $200 \mathrm{~s}$. Here, the time interval between puffs was set to $200 \mathrm{~s}$, which corresponds to a third of the time step for the Eulerian model.

Korsakissok and Mallet (2010b) tested two criteria for the puff injection into the Eulerian host model: a time criterion and a criterion based on the puff horizontal size $\left(2 \lambda_{y} \sigma_{y}\right)$ reaching the grid cell horizontal size. $\lambda_{y}$ is a constant for the effective size of puffs; it is set to 2 in this study (i.e., $95.4 \%$ of the puff material is included) following Seigneur et al. (1981) and Korsakissok and Mallet (2010b).

The sensitivities of modeling results to the puff injection criteria have been reported by Korsakissok and Mallet (2010b). They are summarized here. The use of the time criterion (time elapsed since the emissions from the source), with a $1 \mathrm{~h}$ injection time, improved the performance of the PinG model compared to that of the Eulerian model for a domain with a grid cell size less than about $60 \mathrm{~km}$. The size criterion (puff size commensurate with the grid size) gave better results than the time criterion for a domain with a fine grid cell size $(<25 \mathrm{~km})$; however, the results for a domain with coarser grid cell size were poor because of a greater injection time (more than $6 \mathrm{~h}$ ), which may lead to large errors in puff trajectories. Therefore, the time criterion gave better results than the size criterion for a domain with a coarse grid cell size $(>50 \mathrm{~km})$. 
The time criterion using $1 \mathrm{~h}$ of puff travel time allows one to minimize the number of puffs, which minimizes the computational time. However, the subgrid-scale treatment is then used only near the sources and one may not benefit fully from it. These two injection criteria are used jointly here and the puffs are injected into the corresponding grid cells as soon as one of the two criteria is met. The sensitivity of the PinG model simulation to the puff injection criteria is investigated below, using only the puff size criterion, i.e., using the subgrid-scale treatment over longer distances from the source.

The Gaussian puff model formulation uses similarity theory for the parameterization of the Gaussian standard deviations and the integrated injection for the injection method. In the integrated injection method, puff mass is distributed over the grid cells covered by the puff horizontal and vertical extents (here, $2 \sigma_{y}$ and $2 \sigma_{z}$ ). The detailed parameterizations are given by Korsakissok and Mallet (2010b).

For the comparison of the concentrations calculated in the Reference and PinG simulations, the perturbations of concentrations in non-injected puffs in the PinG simulation are taken into account by injecting the puffs in the corresponding grid cells at the moment of the comparison (and solely for the purpose of the comparison). The integrated injection method is used for this temporary merging of the puffs into the host model.

\subsection{Emissions}

The European Monitoring and Evaluation Programme (EMEP) anthropogenic emission inventory was used for the domains covering Europe and France. Over Greater Paris, the anthropogenic emissions were generated with the 2005 inventory of Airparif, the air quality agency for the Paris region (http://www.airparif.asso.fr/). The surface emissions and aircraft emissions were spatially distributed over the Eulerian grid. There are 196 industrial sources in the domain. Those point source emissions were located in the corresponding grid cell(s) following calculation of the plume rise. Two industrial sites, the Vitry power plant and the Grandpuits refinery were selected for PinG treatment. Therefore, they are treated in the same manner as the other point sources in the Reference simulation and are treated with the subgrid-scale puff model in the PinG simulation. The locations of these two sites are indicated in Fig. 1.

The plume rise is computed in the simulations based on the characteristics of the sources given by Airparif (exhaust velocity, exhaust temperature, stack height, and stack diameter). The Briggs formulae were used for the calculation of the plume rise, as described by Korsakissok and Mallet (2009).

The temporal variation for the emissions was obtained by applying temporal factors available from Airparif. These factors are computed by source categories, which are defined by the SNAP (Selected Nomenclature for sources of Air

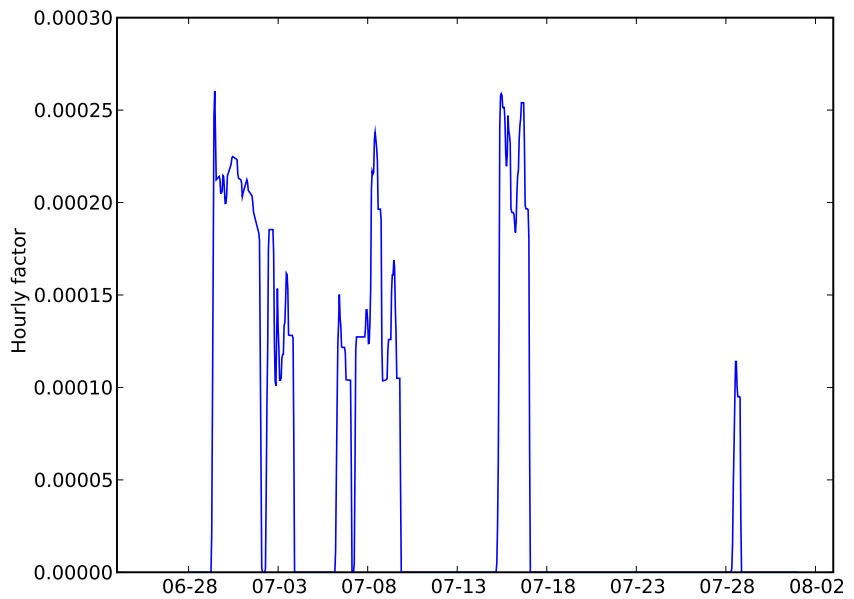

Fig. 2. Hourly factors of the emissions of the Vitry power plant. The hourly factor represents the ratio of the emission rate for a given hour to the annual emission rate. It applies to all gaseous and particulate species.

Pollution) code. Therefore, the factors are generic for a category, and they are not specific to a given source.

Source-specific temporal profiles were used for the sources treated with the subgrid-scale model. For the power plant, the emissions were obtained from data provided by EDF, the operator of the power plant. Figure 2 presents the temporal profile obtained from EDF for the power plant. According to Total, the operator of the refinery, the refinery runs continuously (except for some maintenance operation periods) and the emissions of the refinery were considered to be constant for the entire period of simulation. These sourcespecific temporal profiles are also applied when these sources are treated in the "Reference" simulation.

Emissions of air pollutants from the oil refinery were assumed to be released into the atmosphere from the stack except VOC emissions, which were assumed to occur as fugitive emissions over the entire volume of the refinery, e.g., from tanks, pumps, compressors and valves (Bénassy et al., 2008). Therefore, the VOC emissions from the refinery are treated with a volume source and other emissions $\left(\mathrm{SO}_{2}, \mathrm{NO}_{\mathrm{x}}\right.$ and $\mathrm{PM}$ ) are treated with a point source. For the Grandpuits refinery, the dimensions of the VOC volume source given by Total are $1300 \mathrm{~m}$ (width) $\times 940 \mathrm{~m}$ (length) $\times 20 \mathrm{~m}$ (height) .

Annual emission rates are provided in the Airparif inventory for each species and each point source (tons year ${ }^{-1}$ ). For all other sources, temporal factors (monthly, weekly and hourly) were applied to obtain a hourly factor, which represents the ratio of the emission rate for a given hour to the annual emission rate. The annual emission rates for the Vitry power plant and the Grandpuits refinery are presented in Table 1. The $\mathrm{NO}_{\mathrm{x}}$ emission rate of the Vitry power plant is about three times greater than that of the Grandpuits refinery, while the latter has a greater VOC emission rate than the former. 
Table 1. Annual emission rates of gaseous and particulate species at the two industrial sources (tons year ${ }^{-1}$ ).

\begin{tabular}{ccccccc}
\hline & $\mathrm{SO}_{2}$ & $\mathrm{NO}_{\mathrm{x}}$ & $\mathrm{CO}$ & $\mathrm{PM}_{10}$ & $\mathrm{PM}_{2.5}$ & $\mathrm{VOC}$ \\
\hline Vitry power plant & 4324 & 3088 & 270 & 107 & 49 & 29 \\
Grandpuits refinery & 3778 & 1078 & 409 & 441 & 287 & 540 \\
\hline
\end{tabular}

Table 2. Comparison of the modeled concentrations and observations of the BDQA monitoring network. Performance statistics were calculated with hourly concentration for all species.

\begin{tabular}{cccccccccc}
\hline Stations & $\begin{array}{c}\text { Observation }^{\mathrm{a}} \\
\left(\mu \mathrm{g} \mathrm{m}^{-3}\right)\end{array}$ & $\begin{array}{c}\text { Simulation }^{\mathrm{a}} \\
\left(\mu \mathrm{g} \mathrm{m}^{-3}\right)\end{array}$ & $\begin{array}{c}\text { RMSE } \\
\left(\mu \mathrm{g} \mathrm{m}^{-3}\right)\end{array}$ & MFB & MFE & MNB & MNGE Correlation \\
\hline $\mathrm{PM}_{10}$ & 16 & 20.4 & 10.3 & 13.1 & -0.64 & 0.67 & -0.45 & 0.48 & 0.50 \\
$\mathrm{PM}_{2.5}$ & 6 & 11.7 & 9.2 & 6.5 & -0.19 & 0.46 & -0.02 & 0.47 & 0.47 \\
$\mathrm{O}_{3}{ }^{\mathrm{b}}$ & 45 & 56.4 & 73.5 & 26.6 & -0.08 & 0.17 & -0.05 & 0.16 & 0.73 \\
$\mathrm{NO}_{2}$ & 45 & 16.3 & 13.1 & 11.7 & -0.41 & 0.74 & -0.05 & 0.66 & 0.48 \\
\hline
\end{tabular}

a Mean concentrations over all the stations from 4 July to $29 \mathrm{July},{ }^{\mathrm{b}}$ Threshold of $80 \mu \mathrm{g} \mathrm{m}^{-3}$ (40 ppb).

Biogenic emissions were computed with the Model of Emissions of Gases and Aerosols from Nature (MEGAN) (Guenther et al., 2006).

\section{Results}

Figure 3 presents surface concentrations of $\mathrm{O}_{3}, \mathrm{NO}_{\mathrm{x}}$, $\mathrm{SO}_{2}$ and $\mathrm{PM}_{2.5}$ averaged over the simulation period (429 July 2009) obtained with the Reference simulation for the Greater Paris domain. The results of this simulation are first compared to available measurements. Then, the Reference and PinG simulations are compared and differences due to the PinG treatment are discussed.

\subsection{Comparison to observations}

\subsubsection{BDQA network}

The model evaluation is performed using the hourly concentrations observed at the stations of the BDQA (Base de Données de la Qualité de l'Air) monitoring network. The locations of the BDQA stations, which are in the Greater Paris domain, are shown in Fig. 1.

Table 2 shows the model performance statistics over the entire period and all stations for the concentrations of $\mathrm{PM}_{10}$ (particles with an aerodynamic diameter less than $10 \mathrm{mi}-$ crometers), $\mathrm{PM}_{2.5}, \mathrm{O}_{3}$, and $\mathrm{NO}_{2}$ (nitrogen dioxide). The results are presented only for the PinG simulation because the differences in the performance statistics between the Reference simulation and the PinG simulation are negligible. This close similarity between the performance statistics of the two simulations results from the fact that the plumes from the two industrial sources impact only a few monitoring stations for short periods and have small impacts on region-wide pollutant concentrations. Similar conclusions were obtained in previous PinG modeling studies (e.g., Karamchandani et al., 2002; Korsakissok and Mallet, 2010a). Differences appear when focusing on the impacts of those specific sources, as discussed below.

Standard model performance metrics were used (Yu et al., 2006). For $\mathrm{O}_{3}$, model performance with a mean normalized bias (MNB) of $-5 \%$ and a mean normalized error (MNE) of $16 \%$ is satisfactorily compared with the standard performance criteria $(|\mathrm{MNB}|<15 \%$, MNGE $<30 \%$; Russell and Dennis, 2000). For $\mathrm{PM}_{2.5}$, the mean fractional bias (MFB) and mean fractional error (MFE) are both within recommended performance goals (Boylan and Russell, 2006). For $\mathrm{PM}_{10}$, the MFB $(-64 \%)$ exceeds slightly the performance criteria; however, the MFE $(67 \%)$ is acceptable $(|\mathrm{MFB}|<60 \%$, MFE $<75 \%)$.

\subsubsection{Megapoli campaign}

During the Megapoli campaign of July 2009 (http://www. pole-ether.fr/megapoli/index.jsp), concentrations of various species were measured that are not included in the BDQA measurements. Therefore, model performance is also evaluated here using the Megapoli campaign measurements. Two sites are available for the evaluation of hourly concentrations: SIRTA (Site Instrumental de Recherche par Télédétection Atmosphérique, Haeffelin et al., 2005) and LHVP (Laboratoire d'Hygiène de la Ville de Paris). Model performance statistics are presented in Table 3.

Model performance statistics for $\mathrm{O}_{3}$ and $\mathrm{NO}_{2}$ at SIRTA are similar to those at the BDQA stations and meet the performance criteria for $\mathrm{O}_{3}$. Gas-phase concentrations of isoprene are evaluated at SIRTA. The model reproduces well the temporal variability in the concentrations of isoprene (correlation coefficient: 0.58 ); however, it significantly underestimates the observed values by about a factor of three. This discrepancy can be explained by uncertainties in isoprene 


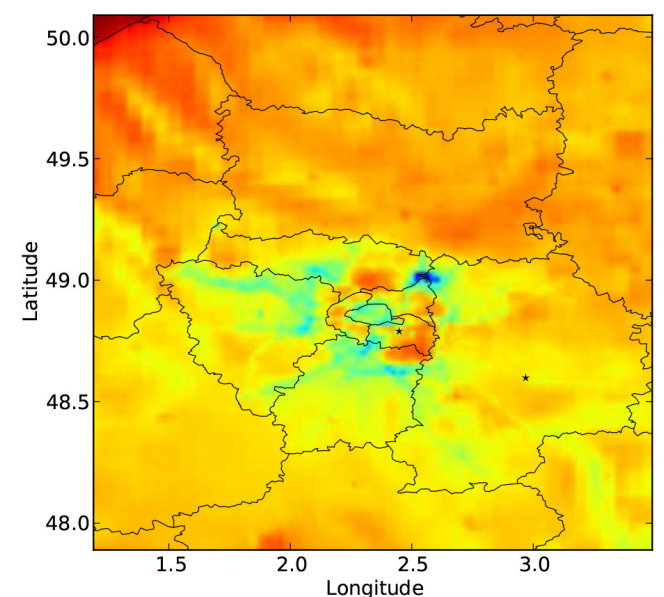

(a) $\mathbf{O}_{3}$

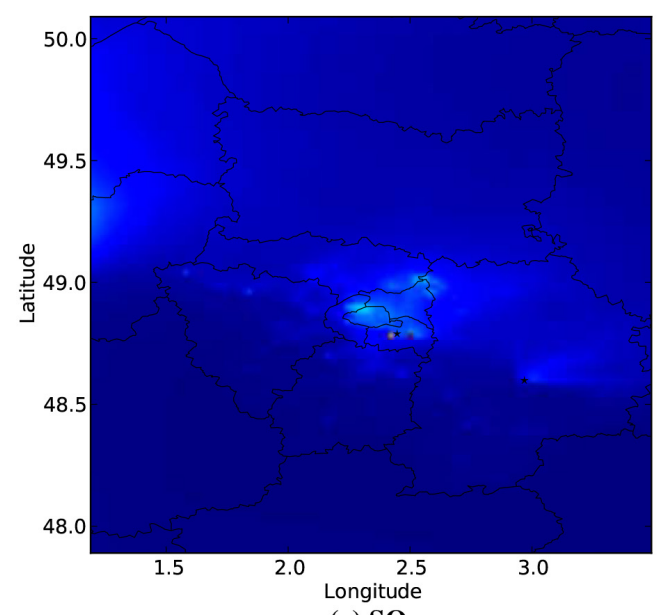

(c) $\mathrm{SO}_{2}$

Fig. 3. Mean surface concentrations for 4-29 July 2009 over the Greater Paris domain obtained with the Reference simulation: (a) $\mathrm{O}_{3}$ (ppb), (b) $\mathrm{NO}_{\mathrm{x}}(\mathrm{ppb}),(\mathbf{c}) \mathrm{SO}_{2}(\mathrm{ppb}),(\mathbf{d}) \mathrm{PM}_{2.5}\left(\mu \mathrm{g} \mathrm{m}^{-3}\right)$.

emissions, which are estimated to be up to a factor of three for specific times and locations when different input variables are used in the emission calculations (Guenther et al., 2006). For elementary carbon (EC) in $\mathrm{PM}_{2.5}\left(\mathrm{EC}_{2.5}\right)$, the correlation is better at SIRTA (correlation coefficient: 0.49 ) than at LHVP (correlation coefficient: 0.27). This result is consistent with a previous model evaluation for EC (Couvidat et al., 2013). However, biases and errors are greater at SIRTA than at LHVP. For organic carbon (OC) in $\mathrm{PM}_{2.5}\left(\mathrm{OC}_{2.5}\right)$ at LHVP, model performance statistics are similar to those for $\mathrm{EC}_{2.5}$ at the station except for greater biases for $\mathrm{OC}_{2.5}$. The performance goals are met for $\mathrm{EC}_{2.5}$ at LHVP but are slightly exceeded at SIRTA and for $\mathrm{OC}_{2.5}$ at LHVP because of an underestimation greater than $30 \%$. For inorganic aerosols, sulfate is underestimated and nitrate is overestimated at SIRTA. The underestimation in the concentrations of sulfate may contribute to the overestimation in the concentrations of nitrate because of interrelated equilibria of ammonium sulfate and ammonium nitrate. This result is typical of current air
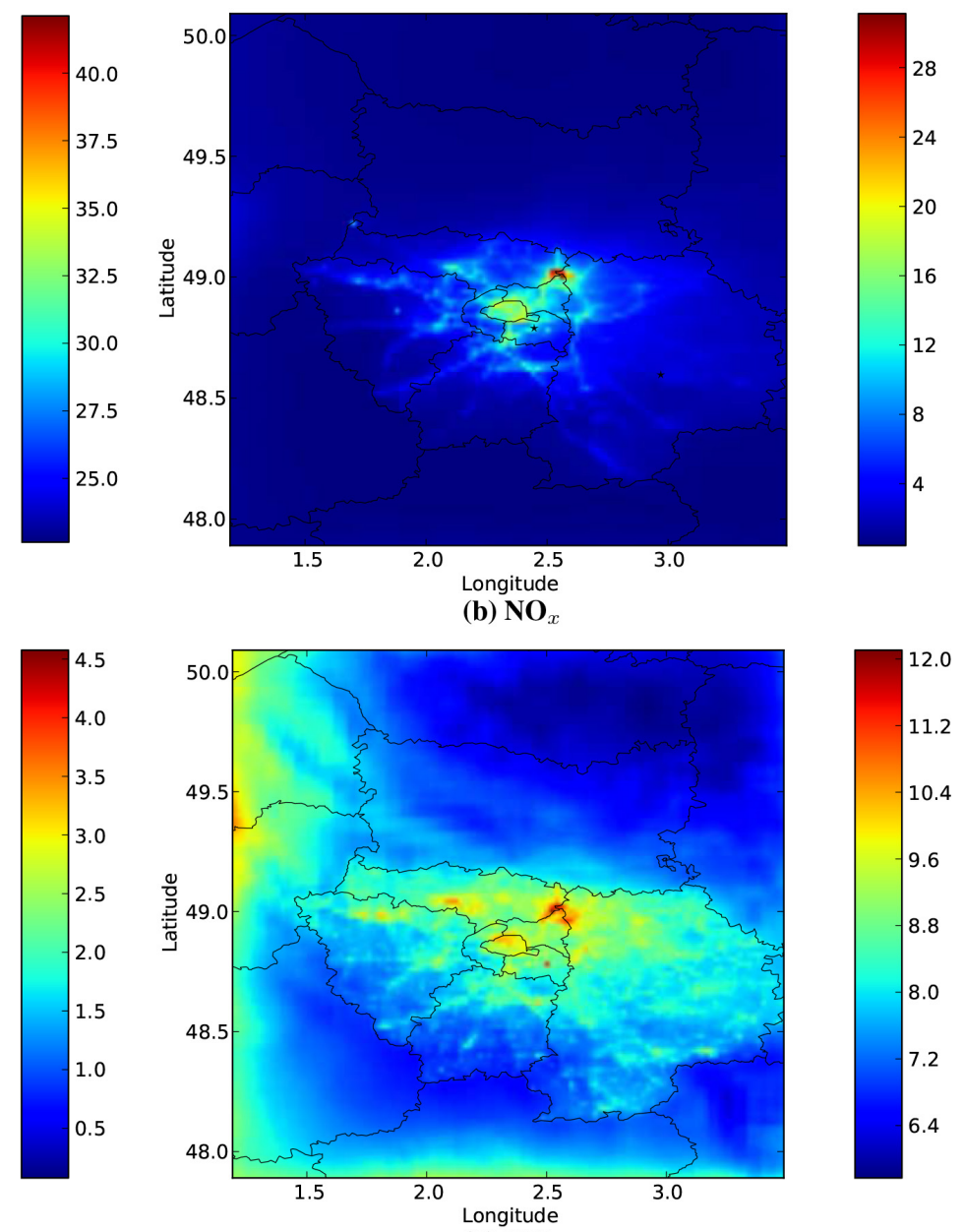

(d) $\mathbf{P M}_{2.5}$

(b) $\mathrm{NO}_{x}$

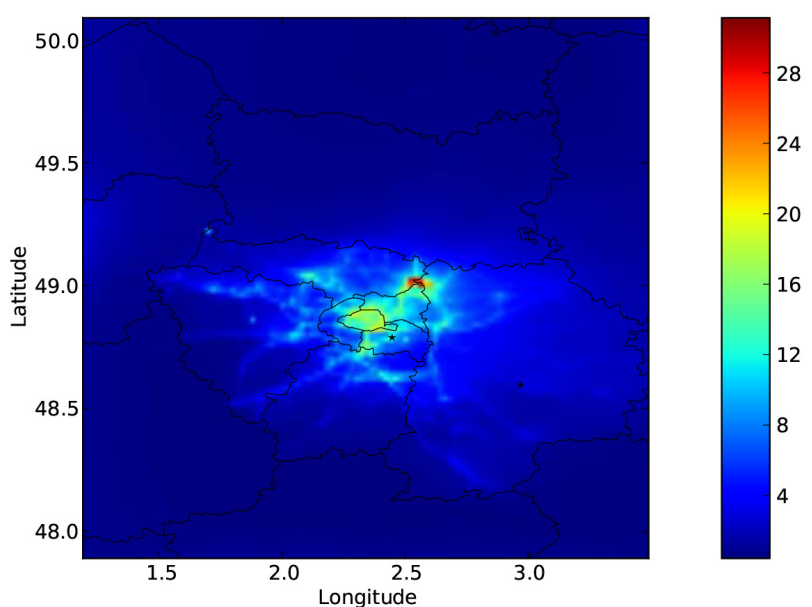

quality model simulations (Solazzo et al., 2012). The concentration of ammonium is better estimated than those of sulfate and nitrate. The performance goal is met by ammonium and almost met by sulfate (a bias of $-31 \%$ versus a goal of $-30 \%$ ), but is not met by nitrate.

Although concentration differences between the two simulations are very small at the measurement sites and over most of the entire domain, local differences can be important near the industrial sources, which are treated in the subgrid-scale model of the PinG simulation, as discussed below.

\subsection{Impacts of PinG modeling on pollutant concentrations}

The spatial impacts of PinG modeling on the surface concentrations of major species are discussed below.

Figure $4 \mathrm{a}$ and $\mathrm{b}$ present the differences in the surface concentrations of $\mathrm{NO}_{\mathrm{x}}$ and $\mathrm{O}_{3}$ between the PinG and Reference simulations, respectively. The differences are averaged over the entire period of simulation (4-29 July 2009). 
Table 3. Comparison of the modeled concentrations and observations during the Megapoli campaign. Performance statistics were calculated with hourly mean concentrations for all species. The units of the simulated and observed concentrations and RMSE are indicated. Other performance metrics are unitless.

\begin{tabular}{|c|c|c|c|c|c|c|c|c|c|}
\hline Station & Species & Simulation $^{\mathrm{a}}$ & Observation $^{\mathrm{a}}$ & RMSE & MFB & MFE & MNB & MNGE & Correlation \\
\hline \multirow{6}{*}{ SIRTA } & $\mathrm{O}_{3}(\mathrm{ppb})^{\mathrm{b}}$ & 42 & 48 & 9.0 & -0.15 & 0.15 & -0.13 & 0.13 & 0.60 \\
\hline & $\mathrm{NO}_{2}(\mathrm{ppb})$ & 5.0 & 4.7 & 4.6 & -0.15 & 0.53 & 0.22 & 0.72 & 0.51 \\
\hline & $\begin{array}{c}\mathrm{EC}_{2.5} \\
\left(\mu \mathrm{gC} \mathrm{m}^{-3}\right)\end{array}$ & 0.42 & 0.60 & 0.51 & -0.34 & 0.44 & -0.23 & 0.36 & 0.49 \\
\hline & $\begin{array}{c}\mathrm{PM}_{2.5} \\
\text { sulfate } \\
\left(\mu \mathrm{g} \mathrm{m}^{-3}\right)\end{array}$ & 0.82 & 1.21 & 0.71 & -0.31 & 0.47 & -0.15 & 0.43 & 0.27 \\
\hline & $\begin{array}{l}\mathrm{PM}_{2.5} \text { nitrate } \\
\quad\left(\mu \mathrm{g} \mathrm{m}^{-3}\right)\end{array}$ & 0.64 & 0.48 & 1.15 & -0.63 & 1.24 & 0.48 & 1.54 & 0.10 \\
\hline & $\begin{array}{c}\text { Isoprene } \\
\text { (ppt) }\end{array}$ & 130.0 & 363.0 & 354.0 & -1.05 & 1.09 & -0.62 & 0.67 & 0.58 \\
\hline \multirow{3}{*}{ LHVP } & $\begin{array}{c}\mathrm{EC}_{2.5} \\
\left(\mu \mathrm{gC} \mathrm{m}{ }^{-3}\right)\end{array}$ & 0.84 & 1.10 & 0.65 & -0.24 & 0.41 & -0.13 & 0.35 & 0.27 \\
\hline & $\begin{array}{c}\mathrm{OC}_{2.5} \\
\left(\mu \mathrm{gC} \mathrm{m}^{-3}\right)\end{array}$ & 2.18 & 3.11 & 1.48 & -0.36 & 0.40 & -0.27 & 0.32 & 0.23 \\
\hline & $\begin{array}{c}\mathrm{PM}_{2.5} \\
\text { ammonium } \\
\left(\mu \mathrm{g} \mathrm{m}^{-3}\right)\end{array}$ & 0.52 & 0.47 & 0.37 & 0.05 & 0.42 & 0.22 & 0.50 & 0.37 \\
\hline
\end{tabular}

${ }^{\mathrm{a}}$ Mean concentrations from 4 July to $29 \mathrm{July},{ }^{\mathrm{b}}$ threshold of $40 \mathrm{ppb}$.

Using the PinG model tends to decrease the concentrations of $\mathrm{NO}_{\mathrm{x}}$ near the location of the point sources. In the PinG model, $\mathrm{NO}_{\mathrm{x}}$ is not immediately dispersed in the grid cells where the sources are situated and it can remain in a plume aloft and be transported farther downwind. However, under conditions where the plumes are rapidly mixed to the ground (here, mostly with westerly winds), the PinG simulation leads to greater surface concentrations near the sources because the emitted material is less dispersed. The concentrations of $\mathrm{NO}_{\mathrm{x}}$ in the grid cells farther downwind of the sources are higher in the PinG simulation than in the Reference simulation because the plume material is released in one or a few grid cells in the PinG simulation, whereas the corresponding emitted material has been dispersed among more grid cells in the Reference simulation.

The surface concentrations of $\mathrm{NO}_{\mathrm{x}}$ are smaller with PinG near the Vitry grid cell $(-1 \%)$; however, they are generally higher with PinG near the Grandpuits grid cell (11\%). These differences can be interpreted by the different characteristics of the sources (see Table 4). The stack height is higher at Vitry $(160 \mathrm{~m})$ than at Grandpuits $(81.5 \mathrm{~m})$. Thus, the $\mathrm{NO}_{\mathrm{x}}$ plumes are emitted at a higher altitude at Vitry. Furthermore, the plume rise is higher at Vitry due to a higher exhaust velocity, although it is partially compensated for by a higher exhaust temperature at Grandpuits. In the simulations, the plumes at the Vitry power plant are emitted at altitudes ranging from 300 to $800 \mathrm{~m}$, whereas the plumes at the Grandpuits refinery are emitted at altitudes ranging from 120 to $300 \mathrm{~m}$.
Table 4. Characteristics of the industrial stacks treated in the PinG model.

\begin{tabular}{lcc}
\hline & $\begin{array}{c}\text { Vitry power } \\
\text { plant }\end{array}$ & $\begin{array}{c}\text { Grandpuits } \\
\text { refinery }\end{array}$ \\
\hline Stack height $(\mathrm{m})$ & 160 & 81.5 \\
Exhaust temperature (K) & 410 & 490 \\
Exhaust velocity $\left(\mathrm{m} \mathrm{s}^{-1}\right)$ & 28 & 8.9 \\
Stack diameter $(\mathrm{m})$ & 5.8 & 4.3 \\
\hline
\end{tabular}

Consequently, the $\mathrm{NO}_{\mathrm{x}}$ plumes touch the ground closer to the source at Grandpuits than at Vitry.

Figure $5 \mathrm{a}$ and $\mathrm{b}$ presents the vertical cross section of the differences in the $\mathrm{NO}_{\mathrm{x}}$ concentrations at Grandpuits and Vitry, respectively. As discussed above, the $\mathrm{NO}_{\mathrm{x}}$ plumes are emitted at higher altitudes at Vitry than at Grandpuits, which leads to a plume touchdown farther downwind at Vitry. Therefore, the impact of PinG modeling on the surface concentrations of $\mathrm{NO}_{\mathrm{x}}$ is greater at Grandpuits than at Vitry. Note that the plumes are transported east of the sources because the prevailing winds are from the west. The greater concentrations in the Reference simulation at the longitude of the source correspond to upwind diffusion.

The differences in the $\mathrm{NO}_{\mathrm{x}}$ concentrations between the two simulations explain the differences in the $\mathrm{O}_{3}$ concentrations. The $\mathrm{O}_{3}$ concentrations near the industrial sources are typically higher with the PinG simulation because the titration of $\mathrm{O}_{3}$ by $\mathrm{NO}_{\mathrm{x}}$ is reduced in the VOC-limited regime of 


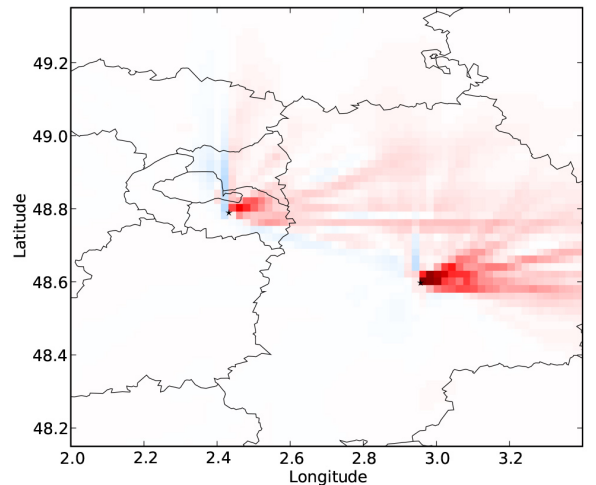

(a) $\mathrm{NO}_{x}$
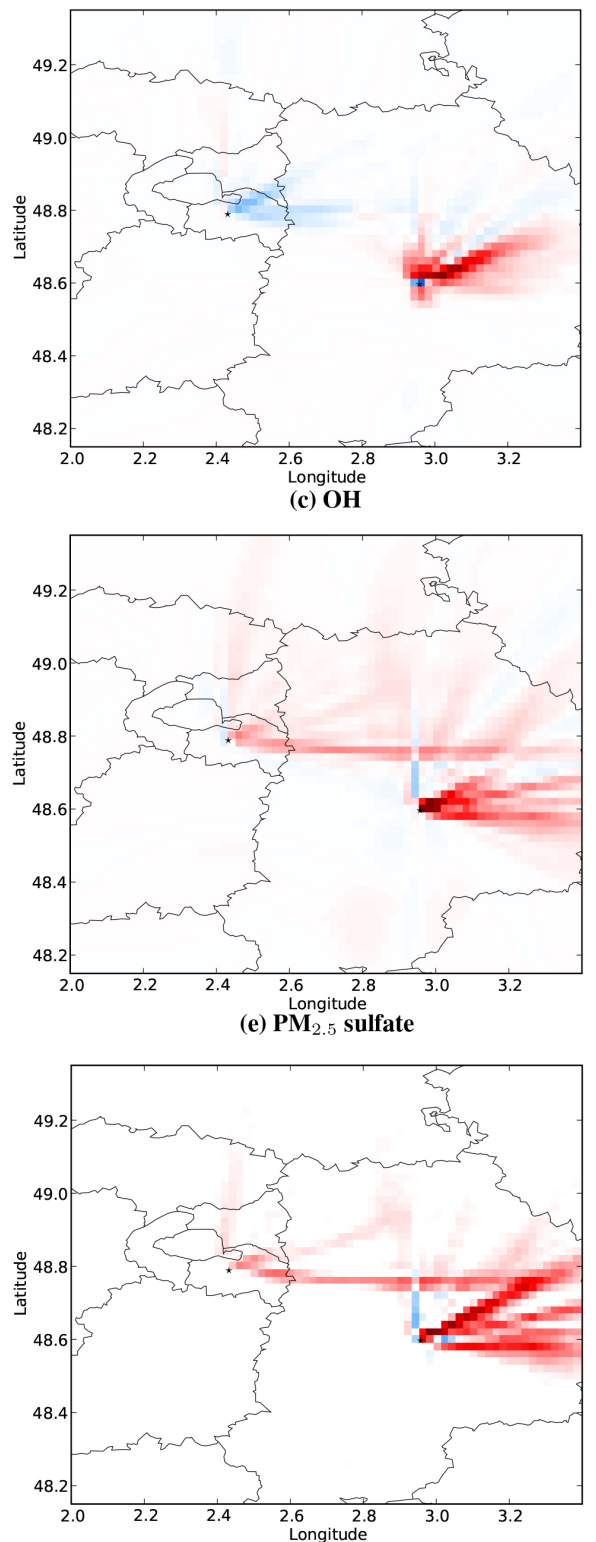

(g) $\mathbf{P M}_{2.5}$ ammonium
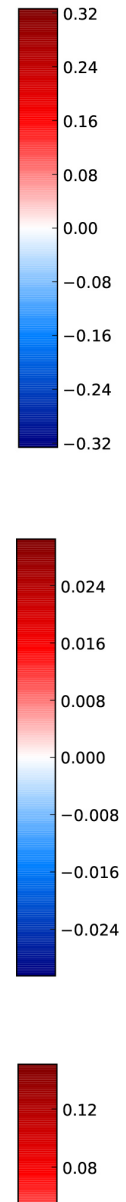

0.04

0.04

$-0.04$

$-0.08$

$-0.12$
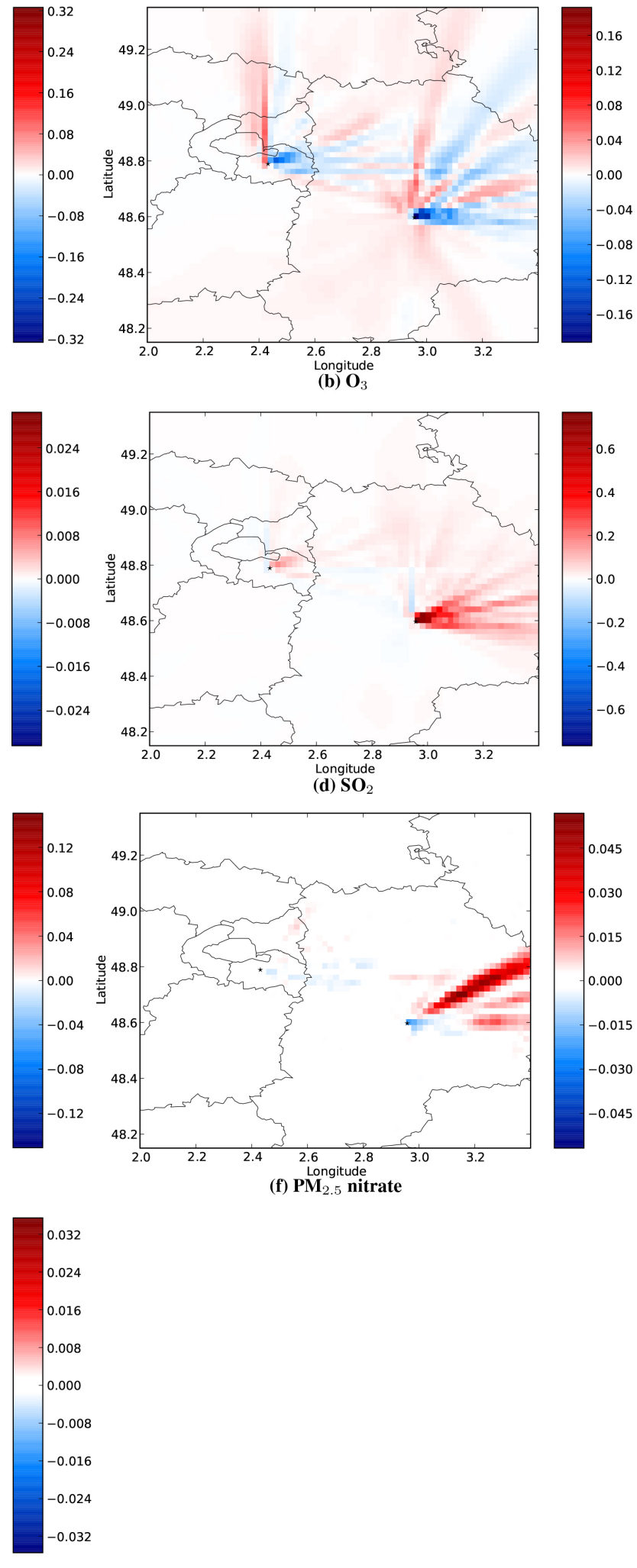

(b) $\mathrm{O}_{3}$

(1)

Fig. 4. Differences (PinG - Reference) in mean surface concentrations for 4-29 July 2009 over the Greater Paris domain: (a) NO $\mathrm{x}_{\mathrm{x}}$ (ppb), (b) $\mathrm{O}_{3}(\mathrm{ppb})$, (c) $\mathrm{OH}(\mathrm{ppt})$, (d) $\mathrm{SO}_{2}(\mathrm{ppb})$, (e) $\mathrm{PM}_{2.5}$ sulfate $\left(\mu \mathrm{g} \mathrm{m}^{-3}\right)$, (f) $\mathrm{PM}_{2.5}$ nitrate $\left(\mu \mathrm{g} \mathrm{m}{ }^{-3}\right),(\mathrm{g}) \mathrm{PM}_{2.5}$ ammonium $\left(\mu \mathrm{g} \mathrm{m}^{-3}\right)$. 

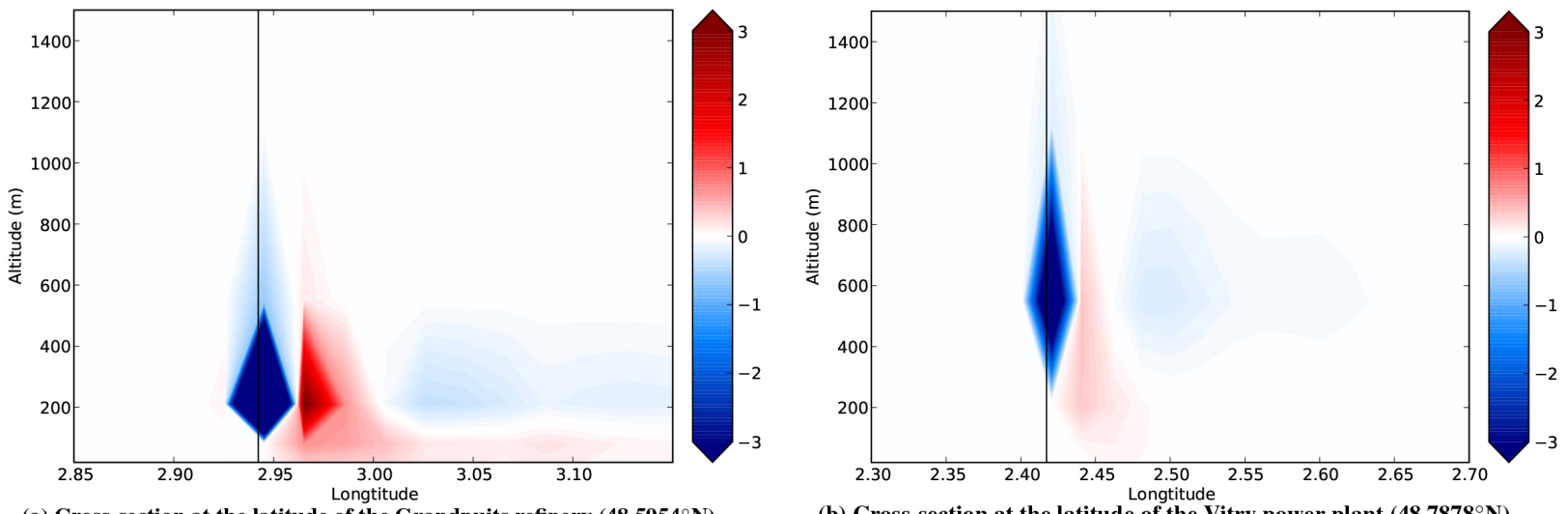

(a) Cross-section at the latitude of the Grandpuits refinery $\left(48.5954^{\circ} \mathrm{N}\right)$.

(b) Cross-section at the latitude of the Vitry power plant $\left(48.7878^{\circ} \mathrm{N}\right)$.

Fig. 5. Vertical cross sections of the differences (PinG - Reference) in the mean concentrations of $\mathrm{NO}_{\mathrm{x}}$ (ppb): (a) Grandpuits refinery, (b) Vitry power plant. The black line corresponds to the longitude of the industrial source.

the Greater Paris region (Kim et al., 2009). However, the concentrations of $\mathrm{O}_{3}$ northeast of Grandpuits are higher with the PinG simulation where the concentrations of $\mathrm{NO}_{\mathrm{x}}$ are also higher. It is due to higher surface VOC emissions in the PinG simulation. As mentioned above, the fugitive VOC emissions at the Grandpuits refinery are treated with a volume source, i.e., VOC are emitted near the surface. The higher concentrations of VOC in the PinG simulation lead to higher concentrations of oxidants, which result in a higher ozone formation (see Fig. 4c). Nevertheless, the impact of PinG on the $\mathrm{O}_{3}$ concentrations is small $(<1 \%)$.

Figure $4 \mathrm{~d}$ and e presents the differences in the surface concentrations of $\mathrm{SO}_{2}$ and sulfate between the PinG and Reference simulations, respectively. The spatial impact of PinG on the concentrations of $\mathrm{SO}_{2}$ shows a tendency similar to that of the $\mathrm{NO}_{\mathrm{x}}$ concentrations. The $\mathrm{SO}_{2}$ concentrations are smaller with PinG near the Vitry grid cell $(-5 \%)$, while they are higher with PinG near the Grandpuits grid cell (50\%). The spatial impact of PinG modeling on the difference in the sulfate concentrations is similar to that of $\mathrm{SO}_{2}$. Sulfate is formed by oxidation of $\mathrm{SO}_{2}$ in the gas and aqueous phases. In the gas phase, the oxidation of $\mathrm{SO}_{2}$ by $\mathrm{OH}$ produces sulfuric acid, which condenses to form particulate sulfate. In the aqueous phase, $\mathrm{SO}_{2}$ is oxidized by $\mathrm{O}_{3}$, hydrogen peroxide $\left(\mathrm{H}_{2} \mathrm{O}_{2}\right)$, and oxygen $\left(\mathrm{O}_{2}\right)$ to form sulfuric acid, which leads to particulate sulfate when the droplets evaporate. The sulfate concentrations in the PinG simulation increase (decrease) with the increase (decrease) in $\mathrm{SO}_{2}$ at Grandpuits (Vitry) (see Fig. 4d). Consequently, the impact of $\mathrm{SO}_{2}$ on the formation of sulfuric acid is more important than that of the oxidants.

Figure $4 \mathrm{f}$ and $\mathrm{g}$ presents the differences in the surface concentrations of nitrate and ammonium between the PinG and Reference simulations, respectively. The impact of PinG on the sulfate concentrations explains the differences in the ammonium concentrations between the PinG and Reference simulations $(-2 \%$ to $6 \%$ ), which are due to the neutralization of sulfate by ammonium. In the case where the sulfate concentrations increase (decrease) with PinG, the ammonium concentrations increase (decrease) according to the concentration of ammonia available. In the case where the sulfate concentrations decrease with PinG, the associated decrease in the ammonium concentrations leads to an increase in gas-phase ammonia concentrations, which results in an increase in ammonium nitrate formation and, therefore, in particulate nitrate concentrations. This phenomenon appears clearly east of the Vitry and Grandpuits sources where sulfate concentrations are lower (higher) in the PinG simulation compared to the Reference simulation, but nitrate concentrations are greater (lower).

\subsection{Impacts of the volume source treatment in the PinG model}

In the previous section, the fugitive VOC emissions at the Grandpuits refinery are treated with a volume source. For further analysis of impacts of the volume source treatment on the VOC emissions, an additional simulation was conducted in which the VOC emissions at the refinery were injected into grid cells as in the Reference simulation, but other pollutants $\left(\mathrm{NO}_{\mathrm{x}}\right.$ and $\left.\mathrm{SO}_{2}\right)$ were emitted through the stack using the point source subgrid-scale treatment. The results of this simulation (hereafter PinG-NonVolumeSource) are compared to those of the PinG simulation.

Figure 6a presents the differences in the concentrations of a VOC, namely toluene. As expected, toluene concentrations are greater. Differences in oxidant concentrations are shown in Fig. $6 b$ and c. The volume source PinG treatment leads to greater oxidant concentrations downwind of the source due to greater VOC concentrations from the refinery fugitive emissions. However, the differences are small $(<1 \%)$ because VOC refinery emissions are a small contribution to total VOC ambient concentrations. Differences in secondary organic aerosol (SOA) concentrations between the PinG and 


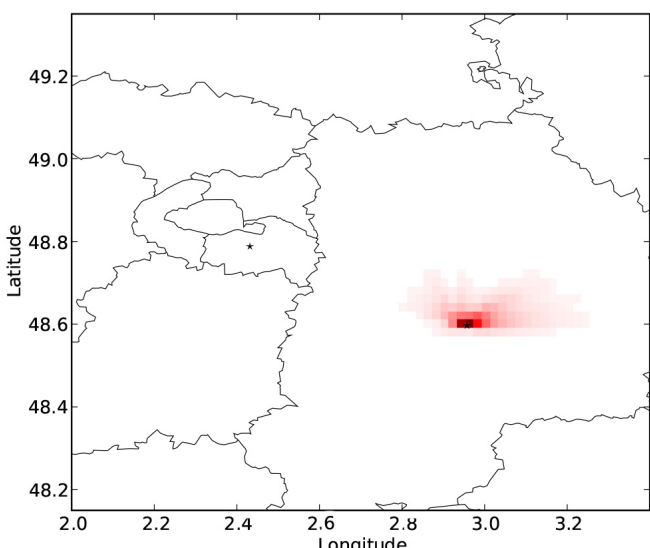

(a) Toluene

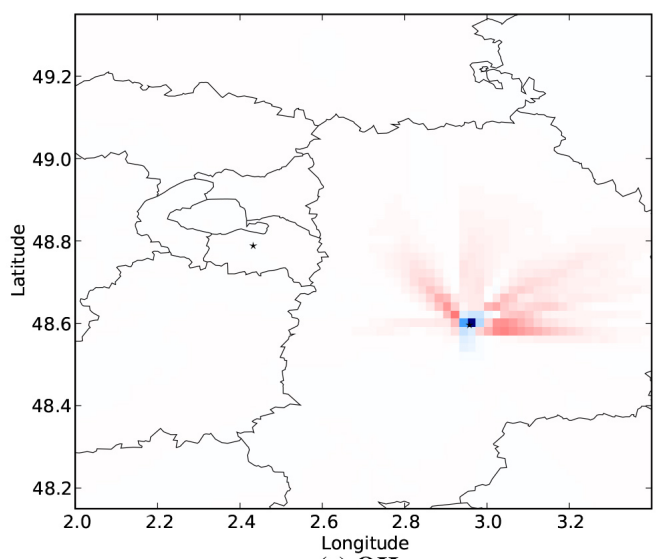

(c) $\mathbf{O H}$

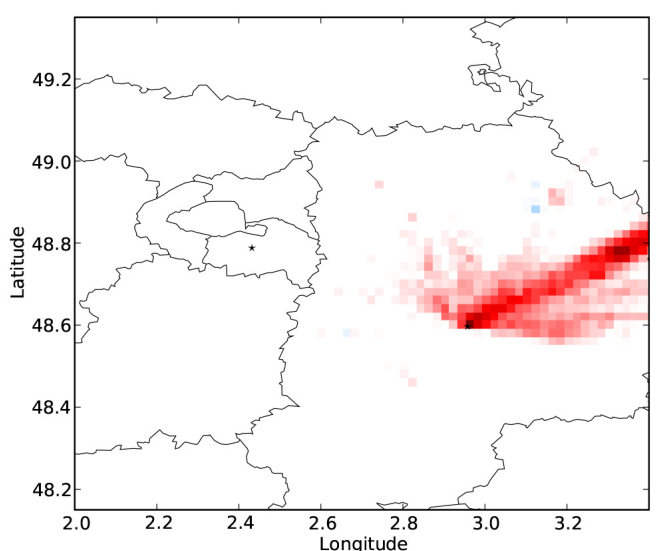

(e) $\mathbf{P M}_{2.5}$ biogenic SOA
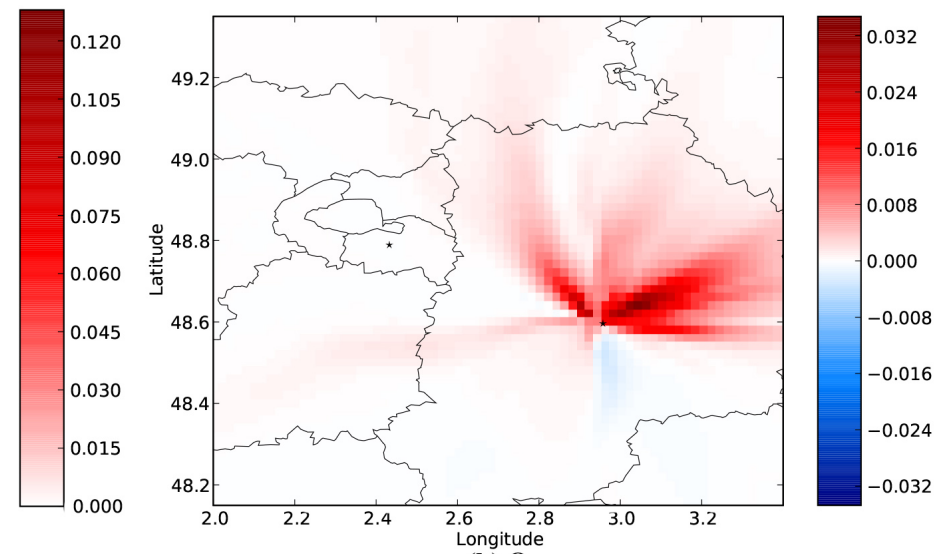

(b) $\mathbf{O}_{3}$
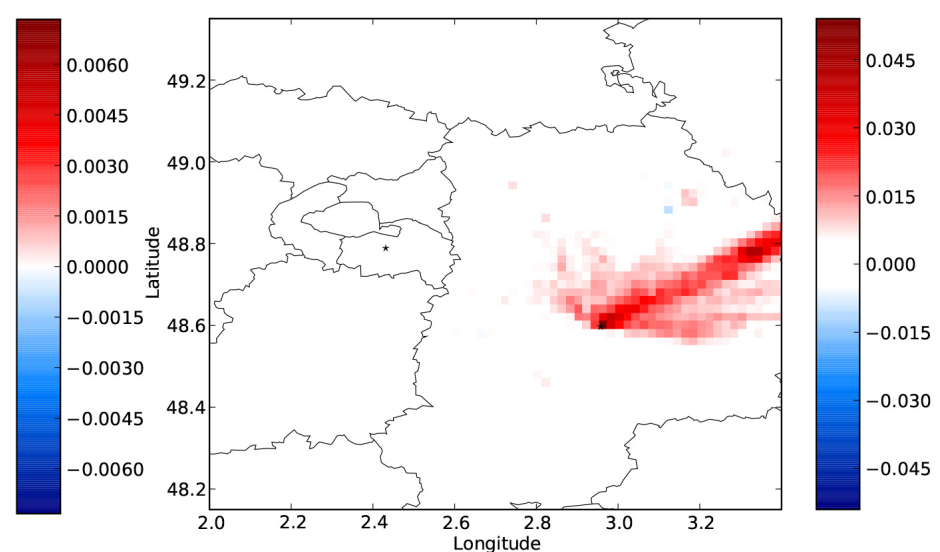

(d) $\mathbf{P M}_{2.5}$ SOA
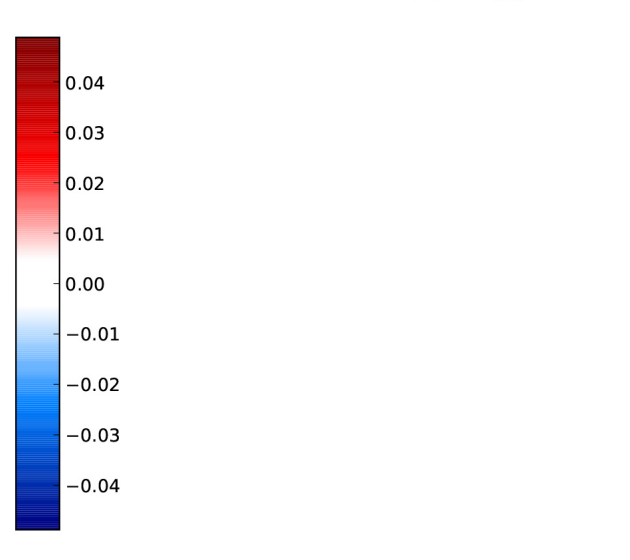


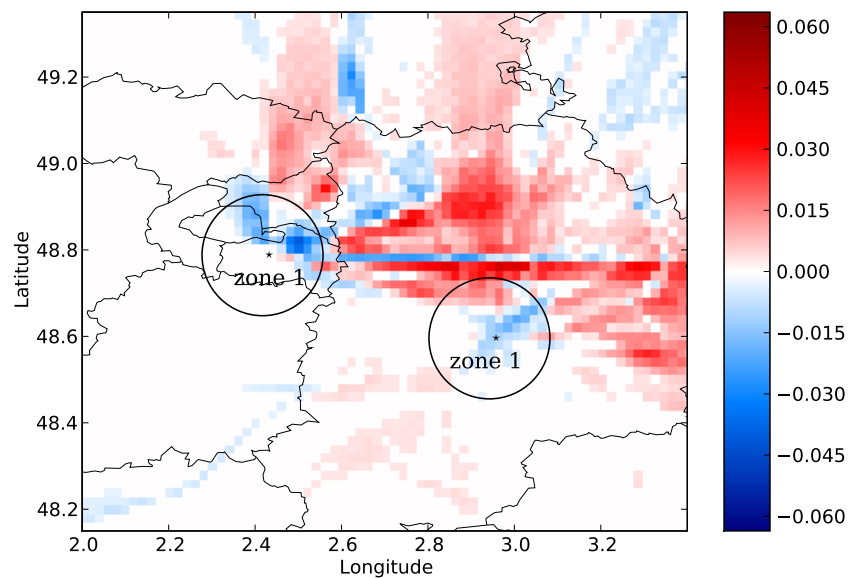

Fig. 7. Differences (PinG - PinG-SizeOnly) in mean surface concentrations of $\mathrm{NO}_{\mathrm{x}}$ for 4-29 July 2009 over the Greater Paris domain (ppb).

(toluene, xylene and glyoxal oligomer). However, the impact of the PinG modeling on the anthropogenic SOA is negligible downwind of the source (not shown). In addition, the contribution of the anthropogenic SOA to the total differences in the concentrations of SOA is rather low (about $10 \%$ of the total differences) even near the source. In fact, the differences in the SOA concentrations are due to differences in the concentrations of biogenic SOA, due mostly to the oxidation of monoterpenes. Since monoterpenes are not emitted from the Grandpuits refinery, the differences in the concentrations of biogenic SOA are due to oxidation of monoterpenes emitted in the surrounding region by oxidants $\left(\mathrm{OH}, \mathrm{O}_{3}\right.$ and $\left.\mathrm{NO}_{3}\right)$, which differ in concentration between the two simulations (see Fig. $6 \mathrm{~b}$ and c). However, SOA concentration differences are small (about $0.05 \mu \mathrm{g} \mathrm{m}^{-3}$ ).

\subsection{Sensitivity to the criterion for puff injection}

A supplementary simulation was conducted using only the size criterion to investigate the influence of the time criterion on PinG modeling. In this simulation (hereafter PinGSizeOnly), the subgrid-scale treatment was extended over larger distances from the source. The results of the PinG simulation conducted above with the two puff injection criteria applied jointly are compared to those of this PinG-SizeOnly simulation.

Figure 7 presents the difference in the surface concentrations of $\mathrm{NO}_{\mathrm{x}}$ between the PinG and the PinG-SizeOnly simulations. The differences can be depicted by defining three spatial zones. The $\mathrm{NO}_{\mathrm{x}}$ concentrations are smaller in the PinG simulation than in the PinG-SizeOnly simulation near the sources up to a distance of about $15 \mathrm{~km}$ (zone 1). Beyond $15 \mathrm{~km}$ downwind of the sources, the $\mathrm{NO}_{\mathrm{x}}$ concentrations become greater in the PinG simulation (zone 2), while they become smaller again in the PinG simulation farther downwind (zone 3). The boundary between zones 1 and 2 is clear for the different plumes. However, the boundary between zones 2 and 3 is not as clear because it depends on the meteorological conditions influencing plume transport. The nearest boundary between zones 2 and 3 is situated at about $50 \mathrm{~km}$ from the sources, but it can be as far as the boundary of the simulation domain.

In zone 1 , the $\mathrm{NO}_{\mathrm{x}}$ concentrations are smaller in the PinG simulation because these situations correspond to low wind speeds, where the emitted pollutants are not transported and dispersed rapidly from the sources. The emitted species staying near the sources are injected earlier into grid cells in the PinG simulation than in the PinG-SizeOnly simulation. The injected species can then be more rapidly dispersed to neighboring grid cells in the Eulerian model. Figure 8a presents the differences in the concentrations of $\mathrm{NO}_{\mathrm{x}}$ between the PinG and the PinG-SizeOnly simulations at 12:00 UTC on 4 July. Wind speeds for grid cells at an altitude of $210 \mathrm{~m}$ where the plumes at the Grandpuits refinery are emitted are less than $2 \mathrm{~m} \mathrm{~s}^{-1}$. The differences are only important near the source. The concentrations of $\mathrm{NO}_{\mathrm{x}}$ are lower in the PinG simulation in grid cells where the plumes are located and they are higher in grid cells that are outside of the plume path because the dispersion following the earlier injection into the grid cells increases the $\mathrm{NO}_{\mathrm{x}}$ concentration. Nevertheless, the mean difference for the whole period is small in this zone (less than $1 \%)$.

In zone 2, the $\mathrm{NO}_{\mathrm{x}}$ concentrations are higher in the PinG simulation. Under higher wind speeds, this zone corresponds to the distance from the source where most of the plumes are injected into the Eulerian model after one hour of the subgrid-scale treatment. $\mathrm{NO}_{\mathrm{x}}$ injected into the Eulerian model in the PinG simulation reaches the ground faster than $\mathrm{NO}_{\mathrm{x}}$ that is transported by the plumes longer in the PinGSizeOnly simulation. The plumes in the PinG-SizeOnly simulation are treated by the subgrid-scale model until the size criterion is met. Figure $8 b$ presents the difference in the $\mathrm{NO}_{\mathrm{x}}$ concentrations between the PinG and the PinG-SizeOnly simulations at 21:00 UTC on 4 July. At that moment, the wind speeds at an altitude of $210 \mathrm{~m}$ are greater than $5 \mathrm{~m} \mathrm{~s}^{-1}$ in grid cells near the Grandpuits refinery. In this figure, there is no significant difference near the source, i.e., in zone 1 . Higher concentrations are simulated in the PinG simulation at distances between 15 and $30 \mathrm{~km}$ from the source.

In zone 3 , the $\mathrm{NO}_{\mathrm{x}}$ concentrations are smaller in the PinG simulation. $\mathrm{NO}_{\mathrm{x}}$ injected into the Eulerian model in zone 2 in the PinG simulation is more easily dispersed to neighboring grid cells. On the other hand, $\mathrm{NO}_{\mathrm{x}}$ transported by plumes to this zone in the PinG-SizeOnly simulation remains more concentrated. In Fig. 8b, lower concentrations are simulated in the PinG simulation at distances between 30 and $45 \mathrm{~km}$. In Fig. 7, mean concentrations of $\mathrm{NO}_{\mathrm{x}}$ between the PinG and the PinG-SizeOnly simulations differ most in this zone (up to $3 \%$ ). 


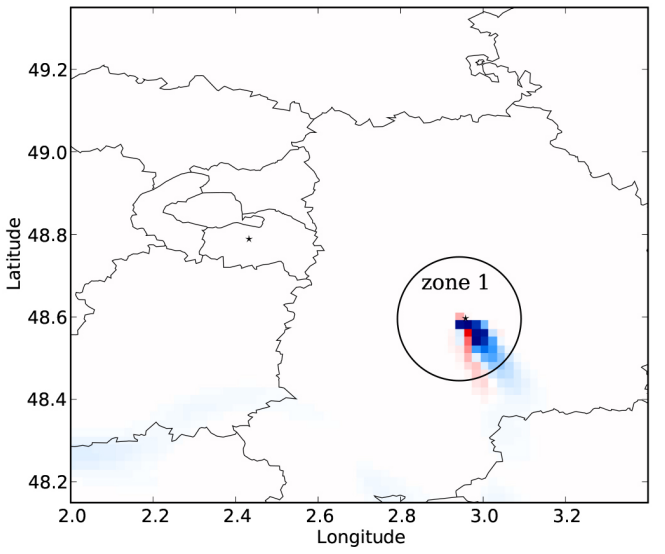

(a) 1200 UTC
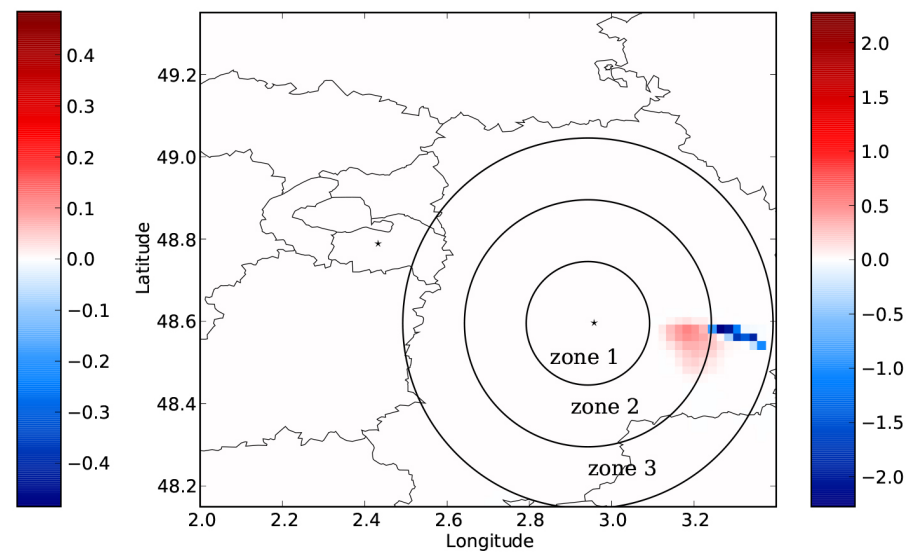

(b) 2100 UTC

Fig. 8. Differences (PinG - PinG-SizeOnly) in the concentrations of $\mathrm{NO}_{\mathrm{x}}$ on 4 July 2009 (ppb): (a) 12:00 UTC, (b) 21:00 UTC. The plume trajectory from the Grandpuits refinery corresponds to the blue grid cells.

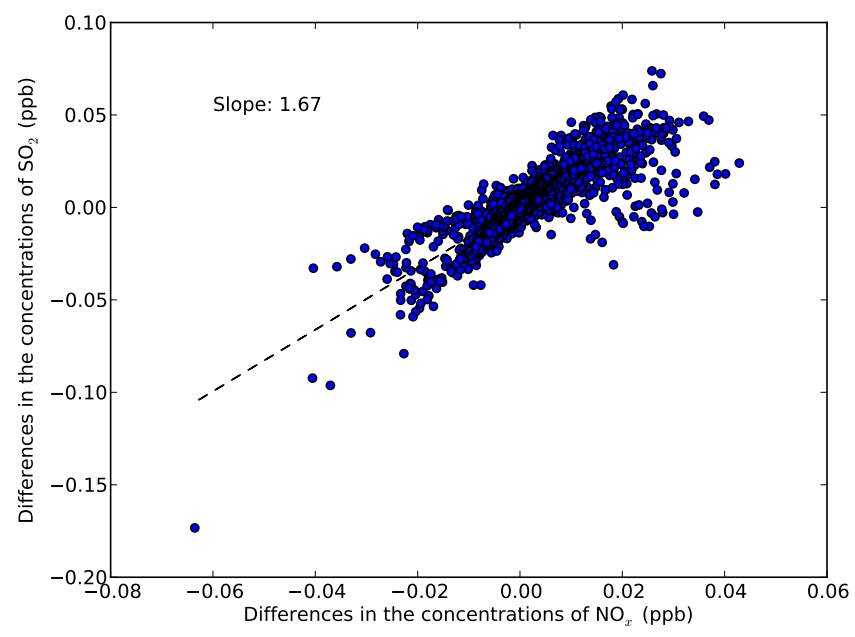

Fig. 9. Scatter diagram of differences (PinG - PinG-SizeOnly) in the mean concentrations of $\mathrm{NO}_{\mathrm{x}}$ and $\mathrm{SO}_{2}$ for 4-29 July 2009 over all grid cells of the Greater Paris domain (ppb).

The differences in $\mathrm{O}_{3}$ concentrations are negligible over the whole domain (less than $1 \%$ ). However, the differences in sulfate concentrations are important in zones 2 and 3; the sulfate concentrations are greater in the PinG simulation in zone 2 (up to $4 \%$ ) and are smaller in zone 3 (up to $5 \%$ ). These differences are due to the differences in the concentrations of $\mathrm{SO}_{2}$, as discussed above. The differences in $\mathrm{SO}_{2}$ show similar tendencies to those in $\mathrm{NO}_{\mathrm{x}}$. However, the maximum difference in $\mathrm{SO}_{2}(15 \%)$ is higher than that of $\mathrm{NO}_{\mathrm{x}}(3 \%)$ because of lower background concentrations for $\mathrm{SO}_{2}$ than for $\mathrm{NO}_{\mathrm{x}}$. Figure 9 presents the relationship between the differences in the concentrations of $\mathrm{NO}_{\mathrm{x}}$ and the differences in the concentrations of $\mathrm{SO}_{2}$, between the PinG and PinG-SizeOnly simulations. The correlation coefficient is 0.86 , reflecting the similar behavior of $\mathrm{NO}_{\mathrm{x}}$ and $\mathrm{SO}_{2}$.

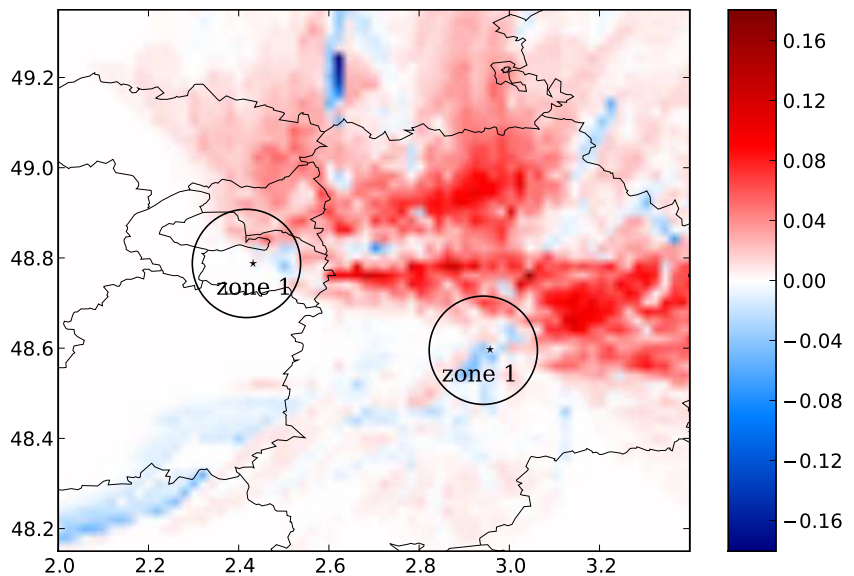

Fig. 10. Relative difference (PinG - PinG-SizeOnly)/(PinG - Reference) in mean surface concentrations of $\mathrm{NO}_{\mathrm{x}}$ with the fine grid size for 4-29 July 2009 over the Greater Paris domain.

Using least-square fitting, the differences in the concentrations of $\mathrm{SO}_{2}$ are on average 1.67 times greater than the differences in the concentrations of $\mathrm{NO}_{\mathrm{x}}$, because of different emission rates and oxidation kinetics.

An indicator, $I$, which quantifies the influence of the time criterion on the pollutant concentrations, was calculated using the following equation:

$I=\frac{C_{\text {PinG }}-C_{\text {PinG-SizeOnly }}}{C_{\text {PinG }}-C_{\text {Reference }}}$,

where $C$ is the concentration in grid cells. Very low $C$ values lead to high $I$ values and can mislead the analysis. Therefore, a threshold value for $\left(C_{\mathrm{PinG}}-C_{\text {Reference }}\right)$ is applied $(0.1 \mathrm{ppb}$ or $\left.\mu \mathrm{g} \mathrm{m}^{-3}\right)$. As expected, the indicator $I$ shows similar patterns as those displayed in Fig. 7 with negative values near the source (zone 1 typical of low wind speed conditions) 


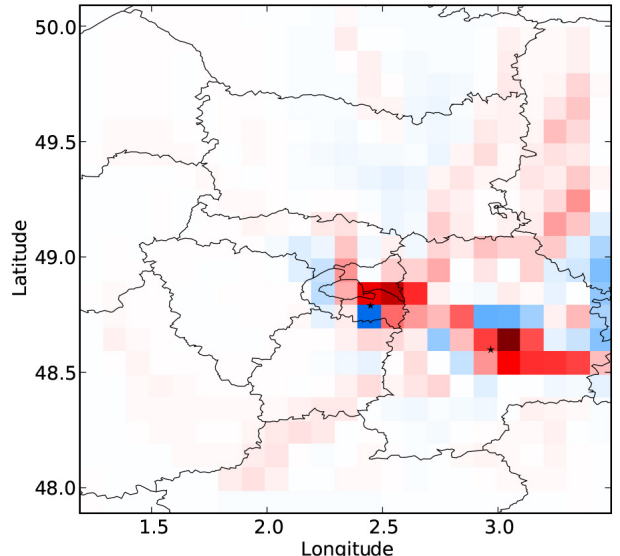

(a) $\mathbf{N O}_{x}$

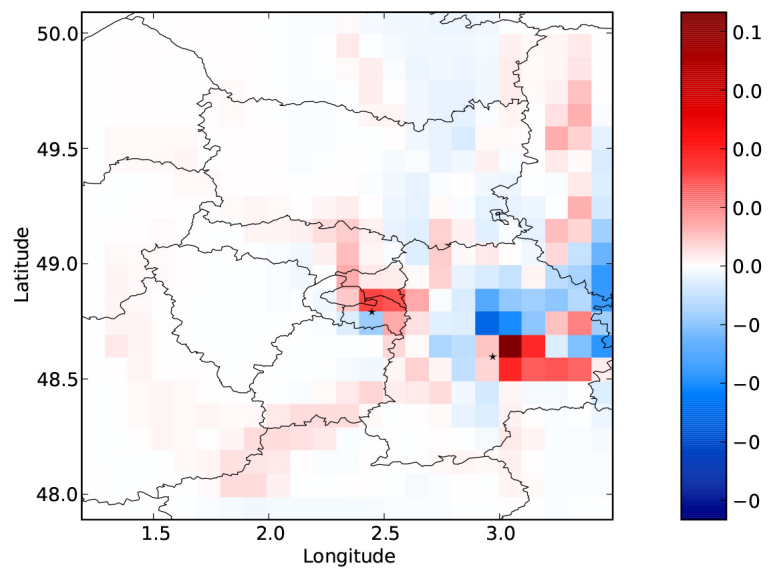

(c) $\mathrm{SO}_{2}$
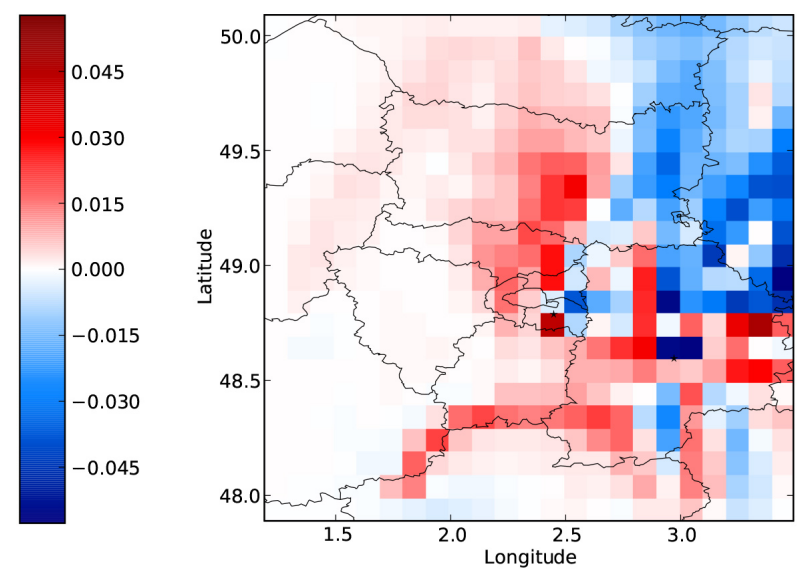

(b) $\mathrm{O}_{3}$

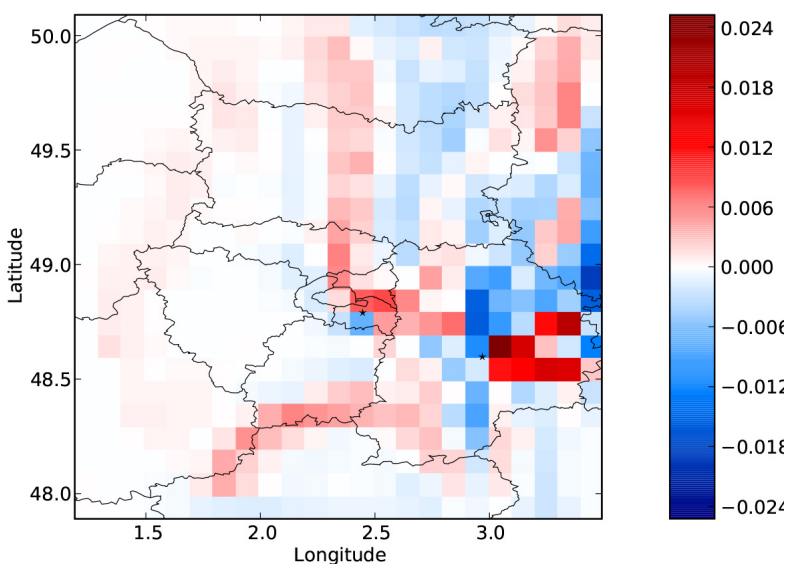

(d) $\mathbf{P M}_{2.5}$ sulfate

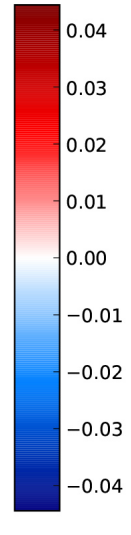

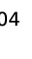

Fig. 11. Differences (PinG - Reference) in mean surface concentrations with the coarse grid size for 4-29 July 2009 over the Greater Paris domain: (a) $\mathrm{NO}_{\mathrm{x}}$ (ppb), (b) $\mathrm{O}_{3}$ (ppb), (c) $\mathrm{SO}_{2}(\mathrm{ppb})$, (d) $\mathrm{PM}_{2.5}$ sulfate $\left(\mu \mathrm{g} \mathrm{m}^{-3}\right.$ ).

and positive values farther downwind (zone 2 typical of high wind speed conditions), as depicted in Fig. 10 for $\mathrm{NO}_{\mathrm{x}}$. The magnitude of $I$ is a measure of the effect of the injection criterion compared to the effect of the use of a PinG treatment. It appears that the latter effect is dominant, as the former is typically $20 \%$ or less of the latter as shown in Fig. 10; similar results were obtained for other species (not shown).

Nevertheless, the effect of the injection criterion is not negligible and the use of the size criterion is recommended. However, it should be considered that trajectory uncertainties become large with long injection times, and an upper limit of $3 \mathrm{~h}$ for the injection time has been recommended for simulations using very coarse grids (Korsakissok and Mallet, 2010b).

\subsection{Sensitivity to the horizontal grid size}

The impact of PinG modeling on pollutant concentrations can be influenced by the choice of the horizontal grid size of the Eulerian host model. For example, the size criterion for the puff injection into the host model is more rapidly met for simulations with a fine resolution because the puff size reaches the grid size faster. Therefore, a sensitivity study of the impact of the grid size on PinG modeling results was conducted. The two simulations (Reference and PinG-SizeOnly) were repeated using the same modeling setup over Greater Paris, except for a coarser horizontal grid size of $0.10^{\circ}$ instead of $0.02^{\circ}$. In this study, the resolution of $0.10^{\circ}$ corresponds to $7.3 \mathrm{~km}$ (east to west domain mean value) $\times$ $11.1 \mathrm{~km}$ (south to north) and that of $0.02^{\circ}$ corresponds to $1.5 \mathrm{~km}$ (east to west domain mean value) $\times 2.2 \mathrm{~km}$ (south to north).

Mean wind speeds at the two vertical levels where the plumes are emitted $(210 \mathrm{~m}$ and $550 \mathrm{~m})$ are $7 \mathrm{~m} \mathrm{~s}^{-1}$ and $7.7 \mathrm{~m} \mathrm{~s}^{-1}$, respectively. Therefore, using the time criterion of one hour would result in most of the puffs being injected into neighboring second or third grid cells from the sources. To avoid such early puff injections, the time criterion for the puff injection was not taken into account and only the puff size criterion was used. Indeed, using solely the size criterion 
in the PinG modeling has been advised for horizontal grid sizes less than $25 \mathrm{~km}$ (Korsakissok and Mallet, 2010b). For consistency in the injection criteria, the results of the simulations for the injection criteria presented in Section 4.4 are used when the sensitivity simulations for the horizontal grid resolution are compared to the simulations with the fine grid resolution.

Figure 11a presents the differences between the Reference and PinG simulations for the $\mathrm{NO}_{\mathrm{x}}$ concentrations. The $\mathrm{NO}_{\mathrm{x}}$ concentrations are smaller in the PinG simulation at Vitry and are greater in the PinG simulation at Grandpuits. These results are consistent with those of the simulation with the fine grid size. However, the maximum difference between the Reference and PinG simulations is about $1 \%$ near the Grandpuits grid cell with the coarse grid size. It is much smaller than that obtained with the fine grid size (11\%). This result seems counterintuitive, but is due to the fact that the comparison is made with grid-averaged concentrations. The grid cell volumes are much greater in the simulations with the coarse grid size, which leads to lower pollutant concentrations with a coarse grid size in the Eulerian host model, and the impact of the PinG modeling is reduced with the coarse grid size. This result is consistent with previous studies. Using coarse grid sizes in Eulerian models leads to lower maximum $\mathrm{NO}_{\mathrm{x}}$ and $\mathrm{O}_{3}$ concentrations because of more diluted $\mathrm{NO}_{\mathrm{x}}$ emissions (Cohan et al., 2006; Henderson et al., 2010). Also, the impact of PinG modeling on the concentrations of a passive tracer increases with finer grid resolutions (Korsakissok and Mallet, 2010b).

Two test simulations were conducted to compare characteristics of puff traveling with the fine and coarse grid size during $24 \mathrm{~h}$. Puffs in the simulation with the coarse grid size can travel longer than in the simulation with the fine grid size. This longer traveling time of puffs can reinforce impacts of PinG modeling in the simulation with the coarse grid size. The traveling times in the simulations are compared in Table 5. The mean puff traveling time with the coarse grid size is twice as great as that with the fine grid size. About $80 \%$ of puffs in the simulation with the coarse grid size could reach the boundaries of the simulation domain without being injected into the Eulerian grid. However, $70 \%$ of puffs in the simulation with the fine grid size were injected into the host model due to the smaller grid size.

Figure $11 \mathrm{~b}$ presents the differences between the Reference and $\mathrm{PinG}$ simulations in $\mathrm{O}_{3}$ concentrations. The lower $\mathrm{O}_{3}$ concentrations in the PinG simulation at the Grandpuits refinery are consistent with those obtained in the simulation with the fine grid size and result from the titration of $\mathrm{O}_{3}$ by NO. The $\mathrm{O}_{3}$ concentrations farther downwind east of the Grandpuits refinery are higher in the PinG simulation in grid cells where the $\mathrm{NO}_{\mathrm{x}}$ concentrations are also higher. This result was explained above by the presence of fugitive VOC emissions, which are emitted near the surface as a volume source. However, the impact of the VOC emissions is less
Table 5. Characteristics of puffs in the simulations with different horizontal grid sizes.

\begin{tabular}{lcc}
\hline & $\begin{array}{c}0.02^{\circ} \\
\text { resolution }\end{array}$ & $\begin{array}{c}0.10^{\circ} \\
\text { resolution }\end{array}$ \\
\hline Emitted puffs & 432 & 432 \\
Injected puffs & 301 & 36 \\
Puffs reaching domain boundaries & 50 & 334 \\
Puffs not injected at the end of & 81 & 62 \\
the simulation & $2.2 \mathrm{~h}$ & $4.7 \mathrm{~h}$ \\
Mean traveling time & & \\
\hline
\end{tabular}

significant because of more diluted VOC concentrations with the coarse grid size (not shown here).

Figure $11 \mathrm{c}$ and $\mathrm{d}$ presents the differences in the surface concentrations of $\mathrm{SO}_{2}$ and sulfate between the PinG and Reference simulations, respectively. For $\mathrm{SO}_{2}$, the impact of the PinG model shows a tendency similar to that of the $\mathrm{NO}_{\mathrm{x}}$ concentrations. The spatial impact of PinG modeling on the difference in sulfate concentrations is similar to that of $\mathrm{SO}_{2}$. However, the sulfate concentrations are lower in the PinG simulation at the Grandpuits grid cell, where the $\mathrm{SO}_{2}$ concentrations are higher in the PinG simulation. It can be explained by lower oxidant concentrations (see Fig. 11b), which lead to lower $\mathrm{SO}_{2}$ oxidation to sulfate. Karamchandani et al. (2006) reported lower sulfate formation when using PinG modeling. In the simulations presented here, however, the effect of the oxidation kinetics is limited and surface concentration differences tend to follow $\mathrm{SO}_{2}$ concentration differences in most parts of the domain. It is likely that the $\mathrm{NO}_{\mathrm{x}}$ emissions are not sufficiently high to alter oxidant fields over long distances because of other significant sources of $\mathrm{NO}_{\mathrm{x}}$ in the Greater Paris region (e.g., on-road mobile sources). Maximum differences in the sulfate concentrations between the PinG and the Reference simulations with the coarse grid size is lower (3\%) than that with the fine grid size (15\%).

\section{Conclusions}

The Polyphemus plume-in-grid (PinG) model was modified to include a full treatment for PM. Furthermore, a PinG treatment for volume sources was developed and a PinG simulation was conducted for the first time for industrial sources of $\mathrm{SO}_{2}, \mathrm{NO}_{\mathrm{x}}$, and VOC.

The impact of PinG modeling over Greater Paris for two industrial sources, a coal-fired power plant and a refinery, was studied. The results show the importance of source characteristics (stack height and diameter, exhaust temperature and velocity) for the surface concentrations of primary pollutants emitted aloft (e.g., $\mathrm{NO}_{\mathrm{x}}, \mathrm{SO}_{2}$, and primary $\mathrm{PM}$ ) simulated with PinG. The impact of PinG on $\mathrm{NO}_{\mathrm{x}}$ leads to an impact on the formation of $\mathrm{O}_{3}$ due to these sources; however, this impact is weak on average because the simulation 
domain is VOC-limited. The formation of sulfate in the subgrid-scale model is mostly influenced by the different dispersion of $\mathrm{SO}_{2}$ in the PinG and Reference simulations and little affected by oxidant concentrations. This result suggests that the relative influence of the precursor (here $\mathrm{SO}_{2}$ ) and oxidant concentrations in PinG modeling is sensitive to the $\mathrm{NO}_{\mathrm{x}}$ and VOC levels in the plume and the relative importance of the source treated at the subgrid scale compared to other sources (e.g., traffic) within the domains. The impact of PinG on nitrate and ammonium concentrations results from the interrelated equilibria of ammonium sulfate and ammonium nitrate. The PinG treatment of VOC fugitive emissions, using a volume source at the oil refinery, plays an important role and leads to higher surface concentrations of VOC, which subsequently lead to slightly greater $\mathrm{O}_{3}$ concentrations. The impact of PinG on the VOC concentrations leads to negligible differences in the concentrations of anthropogenic SOA. Concentrations of biogenic SOA are also influenced by PinG modeling because of differences in oxidant concentrations; however, these differences remain small. The results obtained here reflect the impact of a single fugitive volume source of VOC in a polluted area (Greater Paris). The application of a PinG volume source approach to a heavily industrialized area with multiple VOC fugitive sources should be investigated, as impacts of the PinG approach may then be more significant.

The impact of the time criterion for puff injection into the host model is negligible for $\mathrm{O}_{3}$ (less than $1 \%$ ). Nevertheless, the use of the size criterion is recommended for $\mathrm{PM}_{2.5}$ although an upper limit of $3 \mathrm{~h}$ could be imposed for puff travel times to minimize the effect of uncertainties in puff trajectories. However, it must be noted that the injection criterion has less effect on the air quality simulation than that of the plume-in-grid treatment since the effect of the former on pollutant surface concentrations is typically $20 \%$ or less of the effect of the latter.

When using a coarse horizontal grid size, the impacts of PinG modeling are lower than those with the fine grid size because all concentrations are more diluted in the host Eulerian model with the coarse grid resolution.

The PinG modeling results presented here demonstrate that fugitive emissions need to be taken into account in addition to stack emissions for industrial sites treated at the subgrid scale. The effect of PinG modeling on secondary pollutants is complex and depends strongly on the relative importance of the sources treated at the subgrid scale compared to other sources within the domain.
Acknowledgements. We thank Yelva Roustan, CEREA, for his help in the model development. We also thank Irène Korsakissok, IRSN, and Prakash Karamchandani, Environ, for constructive communications during the model development. We also thank Airparif for providing the emission inventory used for the Greater Paris region. Financial support for this work was provided by Total.

Edited by: R. Sander

\section{References}

Bénassy, M.-F., Bilinska, K., Caluwé, G. D., Ekstrom, L., Leotoing, F., Mares, I., Roberts, P., Smithers, B., White, L., and Post, L.: Optical methods for remote measurement of diffuse VOCs: their role in the quantification of annual refinery emissions, CONCAWE report no. 6/08 available at: https://www.concawe.eu/DocShareNoFrame/Common/GetFile. asp? PortalSource $=1856 \&$ DocID $=15189 \& \mathrm{mfd}=$ off $\&$ pdoc $=1$ (last access: 1 April 2014), 2008.

Boutahar, J., Lacour, S., Mallet, V., Quélo, D., Roustan, Y., and Sportisse, B.: Development and validation of a fully modular platform for numerical modelling of air pollution: POLAIR, Int. J. Environ. Pollut., 22, 17-28, 2004.

Boylan, J. W. and Russell, A. G.: PM and light extinction model performance metrics, goals, and criteria for threedimensional air quality models, Atmos. Environ., 40, 49464959, doi:10.1016/j.atmosenv.2005.09.087, 2006.

Cimorelli, A., Perry, S., Venkatram, A., Weil, J., Paine, R., Wilson, R., Lee, R., Peters, W., Brode, R., and Paumier, J. O.: AERMOD: description of model formulation, available at: http: //www.epa.gov/ttn/scram/7thconf/aermod/aermod_mfd.pdf (last access: 1 April 2014), 2004.

Cohan, D. S., Hu, Y., and Russell, A. G.: Dependence of ozone sensitivity analysis on grid resolution, Atmos. Environ., 40, 126135, doi:10.1016/j.atmosenv.2005.09.031, 2006.

Couvidat, F., Debry, É., Sartelet, K., and Seigneur, C.: A hydrophilic/hydrophobic organic $\left(\mathrm{H}^{2} \mathrm{O}\right)$ model: Model development, evaluation and sensitivity analysis, J. Geophys. Res., 117, D10304, doi:10.1029/2011JD017214, 2012.

Couvidat, F., Kim, Y., Sartelet, K., Seigneur, C., Marchand, N., and Sciare, J.: Modeling secondary organic aerosol in an urban area: application to Paris, France, Atmos. Chem. Phys., 13, 983-996, doi:10.5194/acp-13-983-2013, 2013.

Debry, É., Fahey, K., Sartelet, K., Sportisse, B., and Tombette, M.: Technical Note: A new SIze REsolved Aerosol Model (SIREAM), Atmos. Chem. Phys., 7, 1537-1547, doi:10.5194/acp-7-1537-2007, 2007.

Guenther, A., Karl, T., Harley, P., Wiedinmyer, C., Palmer, P. I., and Geron, C.: Estimates of global terrestrial isoprene emissions using MEGAN (Model of Emissions of Gases and Aerosols from Nature), Atmos. Chem. Phys., 6, 3181-3210, doi:10.5194/acp-63181-2006, 2006.

Haeffelin, M., Barthès, L., Bock, O., Boitel, C., Bony, S., Bouniol, D., Chepfer, H., Chiriaco, M., Cuesta, J., Delanoë, J., Drobinski, P., Dufresne, J.-L., Flamant, C., Grall, M., Hodzic, A., Hourdin, F., Lapouge, F., Lemaître, Y., Mathieu, A., Morille, Y., Naud, C., Noël, V., O'Hirok, W., Pelon, J., Pietras, C., Protat, A., Romand, B., Scialom, G., and Vautard, R.: SIRTA, a ground-based atmo- 
spheric observatory for cloud and aerosol research, Ann. Geophys., 23, 253-275, doi:10.5194/angeo-23-253-2005, 2005.

Henderson, B. H., Jeffries, H. E., Kim, B.-U., and Vizuete, W. G.: The influence of model resolution on ozone in industrial volatile organic compound plumes, J. Air Waste Manage. Assoc., 60, 1105-1117, 2010.

Karamchandani, P., Santos, L., Sykes, I., Zhang, Y., Tonne, C., and Seigneur, C.: Development and evaluation of a state-of-thescience reactive plume model, Environ. Sci. Technol., 34, 870880, doi:10.1021/es990611v, 2000.

Karamchandani, P., Seigneur, C., Vijayaraghavan, K., and $\mathrm{Wu}$, S.-Y.: Development and application of a state-of-thescience plume-in-grid model, J. Geophys. Res., 107, 4403, doi:10.1029/2002JD002123, 2002.

Karamchandani, P., Vijayaraghavan, K., Chen, S.-Y., Seigneur, C., and Edgerton, E. S.: Plume-in-grid modeling for particulate matter, Atmos. Environ., 40, 7280-7297, doi:10.1016/j.atmosenv.2006.06.033, 2006.

Karamchandani, P., Vijayaraghavan, K., and Yarwood, G.: Sub-grid scale plume modeling, Atmosphere, 2, 389-406, doi:10.3390/atmos2030389, 2011.

Kim, Y., Sartelet, K., and Seigneur, C.: Comparison of two gasphase chemical kinetic mechanisms of ozone formation over Europe, J. Atmos. Chem., 62, 89-119, doi:10.1007/s10874-0099142-5, 2009.

Korsakissok, I. and Mallet, V.: Comparative study of Gaussian dispersion formulas within the Polyphemus Platform: evaluation with Prairie Grass and Kincaid Experiments, J. Appl. Meteor. Climatol., 48, 2459-2473, 2009.

Korsakissok, I. and Mallet, V.: Development and application of a reactive plume-in-grid model: evaluation over Greater Paris, Atmos. Chem. Phys., 10, 8917-8931, doi:10.5194/acp-10-89172010, 2010a.

Korsakissok, I. and Mallet, V.: Subgrid-scale treatment for major point sources in an Eulerian model: a sensitivity study on the European Tracer Experiment (ETEX) and Chernobyl cases, J. Geophys. Res., 115, D03303, doi:10.1029/2009JD012734, 2010b.

Kumar, N. and Russell, A. G.: Development of a computationally efficient, reactive subgrid-scale plume model and the impact in the northeastern United States using increasing levels of chemical detail, J. Geophys. Res., 101, 16737-16744, doi:10.1029/96JD01372, 1996.

Nenes, A., Pandis, S. N., and Pilinis, C.: ISORROPIA: A new thermodynamic equilibrium model for multiphase multicomponent inorganic aerosols, Aquat. Geochem., 4, 123-152, doi:10.1023/A:1009604003981, 1998.

Royer, P., Chazette, P., Sartelet, K., Zhang, Q. J., Beekmann, M., and Raut, J.-C.: Comparison of lidar-derived $\mathrm{PM}_{10}$ with regional modeling and ground-based observations in the frame of MEGAPOLI experiment, Atmos. Chem. Phys., 11, 1070510726, doi:10.5194/acp-11-10705-2011, 2011.
Russell, A. and Dennis, R.: NARSTO critical review of photochemical models and modeling, Atmos. Environ., 34, 2283-2324, doi:10.1016/S1352-2310(99)00468-9, 2000.

Sartelet, K. N., Debry, É., Fahey, K., Roustan, Y., Tombette, M., and Sportisse, B.: Simulation of aerosols and gas-phase species over Europe with the Polyphemus system: Part I-Model-todata comparison for 2001, Atmos. Environ., 41, 6116-6131, doi:10.1016/j.atmosenv.2007.04.024, 2007.

Seigneur, C., Tesche, T., Roth, P., and Reid, L.: Sensitivity of a complex urban air quality model to input data, J. Appl. Meteor., 20, 1020-1040, 1981

Seigneur, C., Lohman, K., Vijayaraghavan, K., Jansen, J., and Levin, L.: Modeling atmospheric mercury deposition in the vicinity of power plants, J. Air. Waste Manag. Assoc., 56, 743751, 2006.

Skamarock, W. C., Klemp, J. B., Dudhia, J., Gill, D. O., Barker, D. M., Duda, M. G., Huang, X.-Y., Wang, W., and Powers, J. G.: A description of the Advanced Research WRF version 3, NCAR Technical note-475+STR available at: http://www.mmm. ucar.edu/wrf/users/docs/arw_v3.pdf (last access: 1 April 2014), 2008.

Solazzo, E., Bianconi, R., Pirovano, G., Matthias, V., Vautard, R., Moran, M. D., Appel, K. W., Bessagnet, B., Brandt, J., Christensen, J. H., Chemel, C., Coll, I., Ferreira, J., Forkel, R., Francis, X. V., Grell, G., Grossi, P., Hansen, A. B., Miranda, A. I., Nopmongcol, U., Prank, M., Sartelet, K. N., Schaap, M., Silver, J. D., Sokhi, R. S., Vira, J., Werhahn, J., Wolke, R., Yarwood, G., Zhang, J., Rao, S. T., and Galmarini, S.: Operational model evaluation for particulate matter in Europe and North America in the context of AQMEII, Atmos. Environ., 53, 75-92, doi:10.1016/j.atmosenv.2012.02.045, 2012.

Tombette, M.: Modélisation des aérosols et de leurs propriétés optiques sur l'Europe et l'Ile de France : validation, sensibilité et assimilation de données, Ph.D. thesis, École nationale des ponts et chaussées, 2007.

US EPA: User's guide for the industrial source complex (ISC3) dispersion models, available at: http://www.epa.gov/ttn/scram/ userg/regmod/isc3v2.pdf (last access: 1 April 2014), 1995.

Vijayaraghavan, K., Karamchandani, P., and Seigneur, C.: Plume-in-grid modeling of summer air pollution in Central California, Atmos. Environ., 40, 5097-5109, doi:10.1016/j.atmosenv.2005.12.050, 2006.

Yarwood, G., Rao, S., Yocke, M., and Whitten, G.: Updates to the carbon bond chemical mechanism: CB05 final report to the US EPA, RT-0400675, available at: http://www.camx.com/ publ/pdfs/CB05_Final_Report_120805.pdf (last access: 1 April 2014), 2005.

Yu, S., Eder, B., Dennis, R., Chu, S.-H., and Schwartz, S. E.: New unbiased symmetric metrics for evaluation of air quality models, Atmos. Sci. Lett., 7, 26-34, 2006. 